Review Article

Archives of Disease in Childhood, 1971, 46, 1.

\title{
Bacterial Infection in the Fetus and Newborn
}

\author{
PAMELA A. DAVIES \\ From the Neonatal Research Unit, Hammersmith Hospital, London
}

The significance of potentially harmful influences on the fetus and newborn may be judged in two ways. A direct effect on perinatal mortality is the more easily measured; while subtle damage at a period of very rapid growth may have lasting effects, not always immediately obvious, on the ultimate size and function of organs in survivors. Bacterial infection continues to exert an influence in both ways in the perinatal period, for the impact of antibiotic and chemotherapeutic drugs has been less dramatic than at other ages, and humoral and cellular defence mechanisms may differ qualitatively and quantitatively.

It is difficult to assess the true extent of this problem from the recent literature, largely because criteria for diagnosis are often inexact. It is not always clear for instance whether septicaemia has been diagnosed on blood culture taken from peripheral veins, or from the umbilical vein which may give false positive results (Lipsitz and Cornet, 1960). Even the morbid anatomist's interpretation of his necropsy material is dependent to some extent on the clinician's diagnostic efforts, as inflammatory change may be minimal when death has been rapid from profound bacterial toxaemia. Previous estimates of bacterial infection among stillbirths range from $3-15 \%$, and among neonatal deaths from 10-20\% (Claireaux, 1958), and there may well be racial and geographical variations dependent on social and economic conditions. Even allowing for the fact that neonatal infection is now being sought more energetically, McCracken and Shinefield (1966) suggest a recent increase in the mortality from septicaemia and meningitis. Thus, it may be pertinent to review the various aspects of bacterial and host defence at a time when the fetus can no longer be considered inviolate from marauding Man, and when increasing technical expertise is being lavished on infants who make an untimely exit from the uterus.

The growing interest in this subject in recent years is illustrated by the fact that a request for a Medlars search of the literature from 1963 to the middle of 1969 resulted in the retrieval of 17,147 relevant items. The computer rebelled at the size of this 'print-out' so relieving the writer of a 'readout' which would have extended into senescence. Those interested will therefore be deprived of a complete coverage of the problem, and subjected to a personal and language bias. Much reliance has been placed on previous review articles, so that often, and most regrettably, earlier original work goes unacknowledged.

\section{The Defence Mechanisms of the Host}

The inflammatory response. The inflammatory response produced by the host is usually considered the most fundamental of his defence mechanisms. Freund (1931) showed how young and adult rabbits reacted differently to intracutaneous injections of virulent organisms. An extensive local inflammation occurred in the adults, while the newborn young failed to develop this and died with bacteraemia. In the human infant, the inflammatory exudate in the first days of life has been studied by several workers (Eitzman and Smith, 1959; Prindull, 1968; Bullock et al., 1969), using a modification of the skin window cover-slip technique of Rebuck and Crowley (1955). As in the adult, all have found polymorphonuclear leucocytes predominating in the early cellular response, with mononuclear cells increasing after a 6-hour period. This shift to mononuclear cells is however less rapid and extensive in the newborn. Prindull (1968) has pointed out another difference: in the presence of a raised eosinophil count in the blood, these cells are also seen on the skin cover-slip preparation in the newborn, but not in the adult. He concludes that newly born infants are unable to concentrate their inflammatory cells selectively at the site of inflammation. 
Immunoglobulins. The ontogenesis of immunoglobulins has recently been reviewed by Adinolfi and Wood (1969). There is good evidence that both IgG and IgM are synthesized by the fetus in small amounts, mainly in the spleen, from the 20 th week of gestation onwards. IgE is present in small amounts in cord sera at birth, and as there is no correlation between maternal and fetal levels, the supposition is that it too is synthesized in utero. $\mathrm{IgD}$ on the other hand is absent in cord blood, and so, very frequently, is IgA. Synthesis of these two classes starts gradually after birth, though in the presence of a suitable antigenic stimulus during pregnancy, both IgA and IgM concentrations may be considerably raised in the cord blood. However maternally derived IgG, the only class to cross the placenta, constitutes the bulk of the healthy infant's serum immunoglobulin at birth, gradually disappearing over the first weeks of life.

The transfer occurs largely in the last trimester of pregnancy, and Hobbs and Davis (1967) were able to show a linear relation between the logarithm of IgG concentrations and gestational age, levels at the very low gestations falling below $100 \mathrm{mg}$ / $100 \mathrm{ml}$. Gusdon (1969) demonstrated concentrations consistently about $200 \mathrm{mg} / 100 \mathrm{ml}$ higher than the previous authors, with no significant increase after 33 weeks of gestation, when maternal and infant values became similar. Presumably differences in the racial composition of groups (Hardy et al., 1969), in the amount of placental transfusion, in methods, and in sample size, will account for discrepancies in reported concentrations from various laboratories.

Secreted antibodies concerned with local immunity are mainly of the IgA class, and serum and secretory IgA are not identical (Tomasi et al., 1965), the latter containing a peptide known as 'transport piece' which is synthesized in epithelial cells (South et al., 1966). Transport piece without IgA has been demonstrated in the parotid saliva of newborn infants (South et al., 1968), and in their urine (Remington and Schafer, 1968), and the latter authors suggest that its presence at an early gestation could be of phylogenetic importance, its availability enabling any $\operatorname{IgA}$ produced by the fetus in response to intrauterine infection to be transported to its secretions. IgA starts appearing in secretions shortly after birth (Haworth and Dilling, 1966), and may in fact be found some time before serum IgA is present in detectable amounts, as McKay and Thom (1969) have demonstrated in the tears of the newborn. They could not find any relation between bacterial colonization of the conjunctiva and the time of appearance of $\operatorname{IgA}$ in tears, and supposed that the latter could be associated with antigenic stimulation from organic dust particles in the atmosphere; $\operatorname{IgA}$ in the tears appeared significantly earlier however in both normal and low birthweight infants if they developed an infective conjunctivitis.

The relative paucity of IgM present in the normal newborn compared with the adult is generally held to be responsible for his known susceptibility to Gram-negative infections (Gitlin, Rosen, and Michael, 1963), though Cohen and Norins (1968) have recently demonstrated some antibodies reactive with Gram-negative bacteria in the IgG class. However a quick increase in IgM synthesis, perhaps associated with bacterial colonization of the gut, occurs after birth, though it may be slower in infants of very low gestational age (Berg, 1968). As Adinolfi and Wood (1969) point out, there are several studies testifying to the newborn's ability to produce antibody titres comparable to the adult's following both natural and artificial challenges. Synthesis of IgG proceeds less quickly after birth than that of $\operatorname{IgM}$; and they cite animal and human evidence suggesting that the passively acquired maternal antibody may result in some suppression of immune response. Similarly Hobbs, Hughes, and Walker (1968), reporting raised levels of IgA and $\operatorname{IgM}$ at birth in infants who had undergone intrauterine transfusions, demonstrated that these same children had lower levels of $\operatorname{IgA}$ and $\operatorname{IgM}$ at 1 year than controls.

Overwhelming staphylococcal sepsis was not infrequently seen in the past in mature infants who presumably had the normal adult IgG levels at birth, and thus antistaphylococcal antibody. The ability to synthesize antibody is probably of more immediate importance as a defence mechanism against infection than the possession of passively acquired antibody, and Smith and Eitzman (1964) have urged that, far from making unfavourable comparison with the adult in this respect, we should regard the fetus and newborn as immunologically competent, and capable of developing mechanisms at each stage of existence, which are appropriate for the challenges likely to be met at these times.

Complement. Complement $\left(C^{\prime}\right)$ is the term used for a complex of 11 serum proteins in the globulin fraction. Bacterial cells are lysed by it after their exposure to specific antibody. Its various components are designated numerically (Müller-Eberhard, 1969). Total levels of $C^{\prime}$ in cord blood are less than those of maternal blood (Fishel and Pearlman, 1961), but adult levels are reached by 3 to 6 months of age (Fireman, 
Zuchowski, and Taylor, 1969). It appears that synthesis of complement by the fetus starts before that of the immunoglobulins, and Adinolfi and Gardner (1967) have detected $C^{\prime} 3$ and $C^{\prime} 4$ in fetuses from 15 weeks gestation onwards, though traces of $C^{\prime} 3$ have been present as early as 12 weeks (Adinolfi, Gardner, and Wood, 1968). Fireman et al. (1969) found $C^{\prime} 5$ in addition in the youngest fetus they tested at 18 weeks' gestation, and thought there was a direct correlaticn between gestational age and amount of $C^{\prime} 3, C^{\prime} 4$, and $C^{\prime} 5$ present.

Lysozyme. The role of serum lysozyme in the body's war against bacteria is less important than that of complement and antibody; nevertheless its presence, while not essential, will accelerate lysis and killing of bacteria (Glynn, 1968). Like immunoglobulins and complement, it can be detected in small amounts in fetal sera from early in gestation, its concentration increasing with age. Levels at birth in the mature infant are slightly higher than those in maternal serum (Glynn, Martin, and Adinolfi, 1970). The site of synthesis is as yet unknown. Secretory lysozyme may be more important than serum lysozyme, though levels are not yet documented in fetus and newborn. It is known to be present in appreciable amounts in human colostrum and milk (Glynn, 1968), and colostral IgA which contains antibodies to Escherichia coli has been found to lyse the bacteria only in the presence of complement and lysozyme; whereas the serum fraction (IgM) containing the same antibodies proved bacteriolytic in the presence of complement alone (Adinolfi et al., 1966). It is unfortunate that the sterilization of breast milk by heating to high temperatures under pressure, its subsequent storage at $-20{ }^{\circ} \mathrm{C}$, and thawing and reheating before use, destroys most of its lysozyme (A. A. Glynn, unpublished data). Antibody too will be destroyed by heat, so that infants of low birthweight who are given pooled human milk treated in this way are deprived of virtually all its considerable antibacterial activity, protection which they can ill afford to lose.

C-reactive protein. The appearance of this abnormal protein in the blood, first described by Tillett and Francis (1930), is closely associated with, though not invariably found in, the acute stage of inflammatory illness. It may also be present in some non-bacterial disorders accompanied by tissue destruction (Löfström, 1944). It is frequently detected in maternal serum in the late months of pregnancy, but is not transferred across the placenta; the fetus, however, is capable of its manufacture, for it has been found in a small percentage of cord bloods (Rozansky and Bercovici, 1956; Nemir, Roberts, and Barry-LeDeaux, 1957). The number of positive reactors increases sharply in the first week of life (Felix, Nakajima, and Kagan, 1966). The protein is present significantly more often in cord blood of infants born to mothers whose membranes have been ruptured for more than 24 hours before delivery; and in a small number of infants with proven postnatal bacterial infection significantly more females than males developed a positive test (P. A. Davies, $M$. J. Allington and J. T. Hughes, unpublished data). Ganrot and Kindmark (1969), investigating phagocytosis of bacteria by isolated human neutrophil leucocytes in vitro, have made the tentative suggestion that C-reactive protein may act as a phagocytosispromoting factor.

Phagocytosis. The importance of humoral and cellular factors for effective phagocytosis was first recognized in classic studies by Metchnikoff (1893) and Wright and Douglas (1903). Biochemical investigations and the electron microscope have further increased our knowledge. When bacteria are ingested by a polymorphonuclear leucocyte they are enclosed in a vacuole (Goodman and Moore, 1956; Brewer, 1963). Lysosomes in the neutrophil, which contain various catabolic enzymes, among them lysozyme (Cohn and Hirsch, 1960), then rupture into the vacuole (Hirsch and Cohn, 1960), and the bacteria are killed and digested (Lockwood and Allison, 1963). Metabolic changes in the leucocytes accompany this process, and include increased glycolysis and lactate production, increased oxygen consumption, an increase in hydrogen peroxide formation, and activation of the hexose monophosphate shunt (Karnovsky, 1962). Humoral factors, such as certain immunoglobulins, enhance the efficiency of phagocytosis, and are known as opsonins (Wright and Douglas, 1903).

The study of phagocytosis is fraught with technical difficulties, for the steps necessary to isolate leucocytes may cause cell injury and lead to artefacts (Cline, 1965). The sometimes conflicting results in the newborn reported below will no doubt be resolved once techniques are standardized. For instance, Matoth (1952) compared maternal and cord blood leucocytes in their ability to ingest starch granules. The newborns' leucocytes showed lessened activity, and the opsonizing power of their serum was also decreased. Gluck and Silverman (1957) used carbon particles to demonstrate lessened phagocytic activity as birthweig $^{2} t$ decreased. Edwards, Griffiths, and Swift 
(1958) concluded that cord serum was relatively deficient in a heat-stable phagocytosis-promoting factor, and that cord blood leucocytes were less dependent upon heat labile factors in serum than maternal leucocytes. Miller (1969) endeavoured to separate humoral and cellular factors and study each individually, and showed defects in both compared to adults. Using a different technique, Dossett, Williams, and Quie (1969) could not demonstrate cellular deficiency, though they found opsonic capacity for Escherichia coli impaired. The results of Cocchi and Marianelli (1967) actually suggested an increased phagocytic rate, though less effective killing of ingested Pseudomona aeruginosa in the premature compared with the mature. They supposed this increased activity to be apparent rather than real because of inability to control bacterial growth. Some essentially similar findings were reported by Coen, Grush, and Kauder (1969) in infants less than 12 hours old, and they also demonstrated stimulation of the hexose monophosphate shunt during phagocytosis. Schlegel and Bellanti (1969) proposed that glucose-6phosphate dehydrogenase activity, which is reduced in newborn leucocytes, has a critical role in phagocytosis.

Further work, as yet a little difficult to interpret, concerns the nitroblue-tetrazolium (NBT) dye reduction by neutrophils of the newborn. When this dye is added to in vitro preparations of white cells engaged in phagocytosis it is taken up by them and reduced to formazan, which is easily identifiable as intracellular deposits (Baehner and Nathan, 1967). Park, Fikrig, and Smithwick (1968) believed this test might offer a useful means of differentiating bacterial and non-bacterial illness, but when applied to the newborn, cord blood neutrophils showed an increased NBT reduction (Park et al., 1969), since confirmed by Humbert, Kurtz, and Hathaway (1970). Other studies suggested that the newborn's leucocytes were in an activated metabolic state similar to that of phagocytosis, with significantly increased oxygen consumption, and hexose monophosphate pathway activity (Park, Holmes, and Good, 1970). Cocchi, Mori, and Becattini (1969) have carried out further NBT tests in the first weeks of life on the leucocytes of healthy full-term infants, and low birthweight infants, stated to be premature. The absolute number and proportion of NBT-reduced neutrophils were increased in the full-term infants, and in the low birthweight babies who were healthy or who had non-bacterial disease. A small number with bacterial illness such as 'skin abscesses, pneumonia, septicaemia, etc.' showed consistently and substantially less NBT reduction, even in the presence of leucocytosis, until improvement and recovery took place.

As Grush and Mauer (1969) have pointed out, the enzyme systems concerned with this dye reduction are those associated with normal bactericidal function. On the other hand, when neutrophil bactericidal activity is defective, as in chronic granulomatous disease, an inborn error of phagocytic function (Holmes et al., 1966), the same enzymes may be quantitatively normal (Holmes, Page, and Good, 1967) and released normally (Baehner, Karnovsky, and Karnovsky, 1969), though NBT reduction is greatly reduced (Baehner and Nathan, 1967; Quie et al., 1967). There are other inconsistencies for deficient bactericidal activity is reported in association with normal NBT dye reduction (Thompson et al., 1969), and Grush and Mauer (1969) present evidence to show that spontaneous NBT reduction can occur without neutrophils being in contact with bacteria, suggesting that other conditions associated with increased lysosomal lability, and still to be identified, could have the same effect. We can perhaps conclude that though the main events, both physical and metabolic involved in the ingestion and killing of bacteria are understood, there are connecting links still to be clarified. We can look forward to further developments in this field.

Sex. 'Men on such occasions are almost worse than useless; and then they are so much more liable to infection' (Trollope, 1861). Fanny Robarts was not commenting on the bearing of the male in the neonatal period, though well she might have been. It must be cause for regret that the reason for the increased morbidity and mortality of infant boys, though recognized for many years, has not received more serious scientific scrutiny. Washburn, Medearis, and Childs (1965) reviewed the world literature, as well as Johns Hopkins Hospital case records, on neonatal septicaemia and bacterial meningitis for the period 1930-1963. Infants with congenital anomalies, underlying diseases, or other predisposing causes such as trauma and operation, were excluded. Both meningitis and septicaemia occurred significantly more often in newborn males than in females, even allowing for the excess of male births. Their presumption of a gene locus for immunoglobulin synthesis on the $\mathrm{X}$ chromosome now seems clear from many recently discovered immune deficiency disorders, and Rhodes et al. (1969) found serum IgM levels were directly related to the number of $\mathrm{X}$ chromosomes present. Though differences in the low cord blood levels were unrelated to sex (Hardy et al., 1969), female children 
over 6 years had significantly higher IgM concentrations (Butterworth, McClellan, and Allansmith, 1967). Sex differences in the leucocyte count, present in later life (Allan and Alexander, 1968), or in leucocyte function, do not appear to have been studied in the neonatal period. Schlegel and Bellanti (1969), emphasizing that females have a greater genetic diversity by virtue of their mosaicism for certain maternally and paternally derived genes on the $\mathrm{X}$ chromosome, suggested that the consequences of bearing the glucose-6-phosphate dehydrogenase genes of the mother might be an important reason for the male susceptibility to infection.

\section{Routes and Types of Infection}

Intrauterine. The pathways by which bacterial infection may reach the developing fetus have been clearly summarized (Benirschke, 1960; Blanc, 1961). A transplacental passage from the maternal blood-stream appears to be the most important, though others-from the peritoneal cavity via the Fallopian tubes, from an infected uterine wall, or ascending from the vagina either via ruptured or intact membranes, or between membranes and uterine wall and across the decidua-are at least theoretical possibilities. Biopsy of the fetal membranes in the region of the internal os at term has not infrequently shown degeneration and necrosis (Bourne, 1962), suggesting that even when 'intact' they may be an ineffective barrier. Morison (1963) has pointed out that the large sparse blood vessels and absence of capillaries in the subamniotic tissues of the chorion make the entry of bacteria or bacterial toxins into the fetal blood-stream less likely, and both he and Benirschke and Driscoll (1967) have said how difficult it may be to distinguish the syndrome of ascending infection, in which chorioamnionitis leads to fetal bacteraemia and villous placentitis, from that of blood-borne transplacental spread followed by secondary involvement of the amniotic sac, for the lesions may appear the same. This classification may therefore be somewhat arbitrary.

Transplacental blood-stream infection. As in the numerically more important intrauterine viral infections, the maternal component may be obvious, or pass unnoticed. Two organisms, Listeria monocytogenes and Vibrio fetus, known to be responsible for illness and reproductive casualty in sheep, cattle, and other animals, are now recognized to be pathogenic for Man, the fetus and newborn, with those debilitated by chronic illness appearing especially prone. Though Listeria monocytogenes may be cultured from the cervical secretions (Rappaport et al., 1960) and can thus be acquired by the fetus during passage through the birth canal, examples of probable transplacental haematogenous spread exist, and are described in reviews by Seeliger (1961) and Ray and Wedgwood (1964). Dungal (1961) has also reported such a case, and suggested that 3 previous children born to the same mother, all of whom were mentally retarded and considered to have a congenital malformation of the brain, were in fact victims of listeriosis of the central nervous system. After treatment with oxytetracycline in her fifth pregnancy, this mother was delivered of her first normal healthy child. Lang (1955) found significant anti-listeria titres in a group of children with mental retardation of unknown aetiology, compared with a similar group in whom the cause of retardation was certain. Blood-borne infection may affect many systems of the body, though there is an undoubted predilection for nervous tissue, meningitis being most frequently reported. In those who die at or shortly after birth, miliary lesions may be recognized in organs and placenta, particularly in chorionic villi; these are tiny necrotic foci containing polymorphonuclear leucocytes and the Gram-positive bacilli (Benirschke and Driscoll, 1967). As awareness of this infection increases, and the technical difficulties of culturing and recognizing the organism are overcome, it seems likely, as Barber and Okubadejo (1965) suggest, that more cases of perinatal listeriosis will be recognized and reported.

There are many fewer reported instances of Vibrio fetus infection, and these have been reviewed by Eden (1966). He surmises from the available evidence that the human male acquires the organism from infected animal material, and that transmission to the female is venereal. Neither may manifest any sign of illness, though this has reported with coexisting chronic disease in the adult male (Darrell, Farrell, and Mulligan, 1967). Evidence for transplacental blood-stream infection is scanty, but the report by Hood and Todd (1960), recording recovery of the organism from a necrotic placenta and the brain of a 6-month fetus, is suggestive.

Isolated examples of the transplacental passage of many other bacterial pathogens from mother to fetus are recorded, though less frequently in recent years. An intrauterine meningitis caused by Staphylococcus aureus which had resulted in considerable hydrocephalus was described in an infant born at 38 weeks' gestation. Radiological evidence suggested that the hydrocephalus had been present since the 7th month of pregnancy (Crosby, Mosberg, and 
Smith, 1951). Valdes-Dapena and Miller (1955) have described 2 instances of purulent pericarditis present at birth and culled 9 similar cases from the literature. Both typhoid (Hicks and French, 1905) and tularaemia (Lide, 1947) have been transmitted to the fetus in the course of maternal infection. The pathogenesis of intrauterine tuberculosis has been reviewed by Rich (1951). The fetus is infected very rarely, even though the placenta may contain caseous areas teeming with acid-fast bacilli. This relative resistance may in part be due to the low oxygen tension of fetal blood. When infection does occur, it is usually prominent either in the liver and perihepatic lymph nodes suggesting blood-stream spread via the umbilical vein, or in the lungs due to aspiration of infected liquor.

The lymphocytes of newborn infants of bacteriuric mothers have shown induction of mitosis by Escherichia coli antigen when grown in cell culture (Wallach, Brody, and Oski, 1969). This ability, which indicates previous contact with the antigen, was only very rarely found in lymphocytes from control infants of normal mothers; at 2 to 3 weeks of age on the other hand, it has been universally acquired, presumably as a result of contact with the organism in the course of normal bacterial colonization after birth (Brody and Oski, 1967). Since previous contact in the newly born can only have occurred during intrauterine life, the supposition is that bacteria do not confine themselves to the maternal urinary tract, but perhaps enter the maternal circulation and reach the intervillous space. McKell, Helseth, and Brunson (1960) studied the influence of endotoxin on the placental-fetal 'barrier' in rabbits using trypan blue, and were able to show that in endotoxin-treated animals the dye reached the lumen of vessels in various fetal organs, particularly those of the liver, kidney, brain, and choroid. Patrick (1967) recorded a significantly increased incidence of asymptomatic bacteriuria and clinical pyelonephritis among the newborn infants of bacteriuric mothers compared to controls, but this has not been confirmed by Gower et al. (1970). The association of prematurity and pregnancy bacteriuria postulated by Kass (1962) has been confirmed by some (Stuart, Cummins, and Chin, 1965; Wren, 1969) and disputed by others (Bryant et al., 1964; Dixon and Brant, 1967). Grüneberg, Leigh, and Brumfitt (1969) reported significantly lower birthweights in infants born to bacteriuric mothers compared with controls. As the incidence of pregnancy bacteriuria increases with decreasing socio-economic status (Turck, Goffe, and Petersdorf, 1962), the relation between it, and gestation and birthweight may be complex.
Ascending infection. An inflammatory response may be present in the membranes, the placenta, and the umbilical cord in a proportion of pregnancies. Blanc (1959) reviewed previous work and described the progression of events leading to the full development of what he terms the 'amniotic infection syndrome'. Polymorphonuclear leucocytes arising from vessels in the maternal decidua infiltrate first the amnion and chorion overlying the internal cervical os; the subchorionic intervillous space of the placenta next becomes involved, and is followed by a fetal reaction which starts with migration of leucocytes from vessels on the fetal surface of the placenta and extends to the umbilical cord. The cord is least often involved, but when it is there is a correlation with cord blood cultures positive for Escherichia coli (Kelsall, Barter, and Manessis, 1967), with amnion cultures yielding Gram-negative enteric bacilli (Wilson and Armstrong, 1964), and with an eightfold increase in bacteriologically proven infection in the newborn (Overbach, Daniel, and Cassady, 1970).

Lively discussion on the exact significance of the amniotic infection syndrome in relation to perinatal bacterial infection has been summarized by Benirschke and Driscoll (1967). The histopathological changes may occur in the presence of meconium, or when hypertonic saline is added to amniotic fluid, or if its $p \mathrm{H}$ becomes lowered, or, in the cord, following the mechanical effects of pressure with circulatory slowing. The causative agent seems to lie within the amniotic sac, for polymorph infiltration of the cord does not extend beyond the anterior abdominal wall, and the amnion is more necrotic than the chorion. The sac of the firstborn of twins is affected considerably more than often the second, the likelihood of its presence increases as the interval between membrane rupture and delivery, and since this interval increases as birthweight decreases (Lind and Hytten, 1969) low birthweight and gestation may be disproportionately represented. Though the changes are found with a greater frequency than that of all perinatal disease and certainly far more often than true perinatal infection, it seems unwise to attribute the 'amniotic infection syndrome' to factors other than infection except in a minority of cases.

It is possible to identify those infants who have emerged from potentially infected surroundings, for polymorphs may be demonstrated in placental tissue, in whole mounts of chorion, in the infant's gastric aspirate (Blanc, 1961), in frozen sections of umbilical cord (Benirschke and Clifford, 1959), or in smears from the cut surface of the cord (Aherne and Davies, 1962). Complete absence of polymorph 
infiltration in these situations means that serious bacterial infection acquired in the uterus is very unlikely, and may resolve a clinical dilemma in a sick infant after birth; positive results on the other hand indicate that the baby may have come from an infected environment. As the majority do so unharmed, screening by umbilical cord examination (preferably at the placental end) is probably not justified, though the results of Overbach et al. (1970) suggest its usefulness in prolonged membrane rupture and low birthweight.

The condition most closely associated with the 'amniotic infection syndrome' is that known as congenital pneumonia, a term used to describe lesions found in the lungs of certain infants who are stillborn or die within the first few days of life. A closely parallel incidence of inflammatory reaction in the paranasal sinuses and middle ears has also been described (Benner, 1940). Though the lung alveoli are filled with inflammatory cells, often with degenerate nuclei suggesting their maternal origin (Osborn, 1958; Macgregor, 1960), there may be a striking absence of pleurisy, fibrinous exudate into the alveoli, and infiltration or destruction of bronchopulmonary tissue, features that are common to pneumonias acquired after birth, or as a result of transplacental spread. While many have interpreted this condition as a true fetal infection (Browne, 1922; Johnson and Meyer, 1925; Anderson et al., 1962; Bound, Butler, and Spector, 1956), others (Osborn, 1962; Davies and Aherne, 1962; Olding, 1966) believe such 'pneumonia' to be usually a passively acquired condition due to asphyxial aspiration of polymorph laden amniotic fluid. Analysis of clinical data of mothers and infants (Davies, 1965) gives further support to this view, suggesting that the deaths are mainly due to hypoxia, with bacterial toxaemia a possible contributory cause. While it would be wrong to say that cases in which there is evidence of destructive bacterial aggression and infiltration of bronchopulmonary tissue as a result of ascending intrauterine infection do not occur, this writer feels they are in a minority, and that deaths from congenital 'pneumonia' will lessen as treatment of asphyxia improves.

The condition is said to be two and a half times commoner in the Negro than the white infant (Fujikura and Froehlich, 1967), which suggests there may be a similar difference in the incidence of maternal chorioamnionitis. This increased mortality could be due to an increased number of deaths from intrauterine and birth asphyxia among smallfor-dates Negroes, rather than to the genetic difference in neutrophil response postulated by the authors (see Addendum).
Amniotic fluid and bacterial growth. Derrington and Soothill (1961) suggested that amniotic fluid protein was a selective ultrafiltrate of maternal serum, and demonstrated IgG among its constituents. Failure to find complement (Galask and Snyder, 1970) might conflict with this view, or be due to technical factors, but the presence of lysozyme seems certain (A. A. Glynn and M. Adinolf, unpublished data; Galask and Snyder, 1970). There are differing views of amniotic fluid as a potential culture medium. Some believe it fails to inhibit bacterial growth (Walsh, Hildebrandt, and Prystowsky, 1965; Sarkany and Gaylarde, 1968a), others (Galask and Snyder, 1968; and Florman and Teubner, 1969) that it supports bacterial growth poorly, though when meconium is added it becomes a very good culture medium, particularly for Escherichia coli and Listeria monocytogenes (Galask and Snyder, 1968). Bourne (1962) showed that phagocytes engulfing meconium underwent degenerative change.

During delivery. The majority of infants probably do not encounter bacteria or their toxins until they reach the vagina. According to Weinstein (1938), there appears to be little variation in vaginal flora between pregnant and non-pregnant individuals, despite the higher hydrogen ion concentration of the vaginal secretions during pregnancy. Staphylococci, streptococci, diphtheroid organisms, and anaerobes are the common inhabitants, Escherichia coli being less often found. Antibiotics may have a modifying influence, not all aspects of which are desirable. Following ampicillin treatment to febrile women in labour, all types of streptococci disappeared, Escherichia coli and Proteus mirabilis species lessened, and Klebsiella species and other Gram-negative bacilli, largely resistant to antibiotics, increased (Felton and Williams, 1967). The effect of antibacterial creams used during pregnancy and labour on the vaginal flora is not known.

Pathogens such as Listeria monocytogenes or Neisseria gonorrhoeae harboured in chronic cervical lesions may be acquired by the newborn in their passage through the birth canal and cause serious infection. Maternal carriers of bowel pathogens, often symptomless, may also infect their infants during delivery, and outbreaks of salmonellosis and shigellosis as well as infections with enteropathogenic coliform organisms have started in this way in newborn nurseries (Ensign and Hunter, 1946; Cooper et al., 1959; Salzman, Scher, and Moss, 1967; Rowe, Giles, and Brown, 1969). 
Postnatal infections. After birth the infant is at the mercy of his environment. He may acquire infection from the hands of his attendants, from apparatus used in his resuscitation or general care, particularly from the humidifying units of such equipment, from the air, or from his feeds.

\section{Bacterial Colonization}

Initial flora. The acquisition of certain bacteria after birth by the upper respiratory and gastrointestinal tracts and skin is part of normal developmental physiology. Such colonization is usually considered beneficial, but the dividing line between a normal and an invasive flora may be narrow in the neonatal period. Immediately after delivery, Sarkany and Gaylarde (1967) found coagulasenegative staphylococci and diphtheroids on the skin of the newly born, the organisms they cultured from the maternal vagina just before delivery. The skin of infants born by caesarean section was sterile. Sprunt and Redman (1964) tested vernix caseosa in vivo and in vitro for evidence of antibacterial activity, and concluded that if vernix had any ability to support the survival of bacteria, it was no greater than that of skin alone. Vernix is usually removed with the first ritual bath within a few hours of delivery, and if this is conducted with soap and water alone, the type and numbers of organisms recovered from the skin before and after the procedure are little different (Sarkany and Gaylarde, 1968b).

Whether delivery of the mother is made by the vaginal or abdominal route however, cultures of the infant's nose, throat, umbilicus, and rectum made immediately after birth are sterile in the majority. Over the first days of life, there is a steady increase in colonization at these sites, and it occurs most rapidly in the rectum. Several workers are agreed that the umbilicus becomes colonized more quickly than the nose, and certain areas of the skin such as the perineum and axillae may become more heavily colonized than others (Torrey and Reese, 1945; Smith and Bloomfield, 1950; Hurst, 1960; Davies et al., 1970).

While some of the initial flora at sites other than the skin may also be acquired from the birth canal, feeding practices and the infants' new environment assume increasing importance. Babies who were entirely breast-fed had coliform bacilli isolated from their throat less often than those partly or completely artificially fed (McFarlan, Crone, and Tee, 1949). Gram-positive bacilli made up over $90 \%$ of their stool flora, and distal to the caecum the $p \mathrm{H}$ was consistently lower, in the presence of increasing numbers of lactobacilli, whereas the flora of the artificially fed was much more variable (Barbero et al., 1952).

Acquisition of environmental flora. The problem of staphylococcal illness which many hospitals faced in the 1950's, and which was by no means confined to their maternity units, has gradually resulted in a better understanding of the acquisition and dispersal of this organism by patients and staff. It appears that some individuals, not necessarily ill, and including both newborn infants (Eichenwald, Kotsevalov, and Fasso, 1960) and adults (Hare and Thomas, 1956) are heavy dispersers of staphylococci from their skin into the air. The perineum has been shown to be a particularly heavily contaminated site (Hare and Ridley, 1958). The bacteria are carried on epithelial scales which become detached by movement, friction of clothing, or bedding, and dispersed into the environment (Davies and Noble, 1962). Though the majority of heavy dispersers, as well as others who are not, show nasal carriage of staphylococci, significant dissemination from this source, or from the mouth during ordinary conversation, is rare though obviously increased by sneezing or coughing (British Medical Journal, 1960). The organisms carried on shed skin scales survive for considerable periods in dust, but airborne contamination is only partly responsible for floor deposition, and other sources such as shoes and trolley wheels are thought to be equally important (Ayliffe et al., 1967).

It seems almost certain that staphylococci are transferred to the newborn infant in the first place by the hands of his attendants (Frappier-Davignon, Frappier, and St.-Pierre, 1959; Wolinsky et al., 1960; Hurst, 1960; Mortimer et al., 1962). Winton and Keay (1968) think otherwise, believing the ward air to be the main depot. Though the hands of over $50 \%$ of the attendant staff of their newborn nursery yielded these organisms they showed that the main 'pattern' (a combination of predominant phage group isolated with most frequently occurring antibiotic sensitivity category) was different from that of the infants, though less frequently encountered patterns might be common to both. They postulated that the two groups did not abstract the same staphylococci from the air to form their dominant colonizing strains, though presumably some differential abstraction by infants from attendant hands could also occur. Love et al. (1963), who found their nurses' hands contaminated $2 \%$ of the time, calculated that babies handled 20-30 times daily had a chance probability of contact by contaminated hands approximately once on alternate days. 
Gram-negative bacilli are found in dust much less frequently than Gram-positive organisms, but a whole host of them flourish in water and form a particular hazard for the humidifying units of apparatus from where they may be transmitted to infants (Sever, 1959). These 'water bugs' have been the cause of many nursery epidemics (American Journal of Diseases in Children, 1961). Perhaps the most notorious opportunist of them all, and the most frequently reported, is Pseudomonas aeruginosa. It has been isolated from incubators (Barrie, 1965), suction and resuscitation apparatus (Bassett, Thompson, and Page, 1965; Rubbo, Gardner, and Franklin, 1966), ventilators (Phillips and Spencer, 1965), breast pumps (Thom, Cole, and Watrasiewicz, 1970), eye drops, hand lotions, and other disinfectant fluids (Medical Research Council, 1968; Morse and Schonbeck, 1968), and sinks, washbasins, and their traps (Wilson et al., 1961; Fierer, Taylor, and Gezon, 1967). From the latter trio it is almost impossible to eradicate (Kohn, 1967). Its faecal carriage by infants is often prolonged and the presence of the same strain has been documented in a nursery over many months (Jellard and Churcher, 1967).

Though the hands may play a secondary role where the 'water bugs' are concerned, they no doubt transmit the enterobacteriae back to the infant (Balassanian and Wolinsky, 1968), as seems likely in adult patients (Salzman, Clark, and Klemm, 1967), so that the acquisition of Escherichia coli for instance may be the same as the staphylococci, though their environmental habitats differ. Colonization of the throat with Gram-negative organisms is significantly less likely in healthy mature infants nursed with their mothers, than in ill and low birthweight infants in a special nursery (Farmer, 1968; Davies et al., 1970), and sick infants in such nurseries are more likely to be colonized with Gram-negative bacteria than well infants, whether mature and of normal weight, or of low birthweight (Davies et al., 1970).

Bacterial flora and illness. When infants are heavily colonized at sites other than the rectum, they are more likely to have bacterial infections than if lightly or insignificantly colonized. This holds true whether such colonization is staphylococcal (Gillespie, Simpson, and Tozer, 1958) or Gram-negative (Davies et al., 1970). When colonization with Staphylococcus aureus is not a factor, bacterial infections are more likely to occur in those moderately or heavily colonized with Gram-negative bacilli, among whom are a significant excess of males, than with Gram-positive or mixed flora (Davies et al., 1970). Where staphylococcal infection was concerned, most investigators found nasal carriage and sepsis more common among the hospital born (Gairdner, 1954; Elias-Jones, Gordon, and Whittaker, 1961; Medical Research Council, 1967). Forfar et al. (1966) on the other hand reported a higher staphylococcal mortality in the first three months of life among infants born at home, while Williams (1961) could find no significant difference in nasal carriage between the two.

It is important to realize that there are few if any bacterial species which cannot be pathogenic to the fetus or newborn, and cause widespread and lethal illness. A particular organism may give rise to a variety of illness, in part due to differing strains of organisms, in part due to route of entry, and local factors such as trauma or congenital malformations. Thus Pseudomonas aeruginosa has caused otitis media in one epidemic (Victorin, 1967), and necrotizing enterocolitis in another (Henderson, Maclaurin, and Scott, 1969). Certain strains of Escherichia coli have been responsible for epidemic pyelonephritis (Kenny et al., 1966), and Staphylococcus aureus has on occasion had a predilection for the peritoneum (Beaven, 1958). Skin sepsis ranging from minute pustules to severe exfoliation may be caused by staphylococcal infection (Lee et al., 1952); while indurated erythematous rashes have been reported with some of the 'water bug' infections (Foley et al., 1961), and necrotic lesions with Pseudomonas aeruginosa. A peculiar foul smelling purple-coloured necrosis of brain tissue has been reported with enterobacterial infection (Cussen and Ryan, 1967; Shortland-Webb, 1968), with intense underlying vasculitis and infarction.

Many of the bacteria responsible for serious illness in the newborn are listed in Table $I$.

Changing ecology. While coliform infections have for long been regarded as a particular hazard of the neonatal period, the bacterial colonization of the newborn has shown changing patterns. Earlier reports of neonatal infection commonly incriminated the $\beta$-haemolytic streptococcus, an organism responsible for puerperal fever, a cause of much maternal morbidity and even mortality (Colebrook and Kenny, 1936; Boissard and Eton, 1956). During the 1940's and 1950's, the haemolytic streptococcus was gradually ousted by Staphylococcus aureus, and reports began to appear from many parts of the world describing the widespread colonization of the newborn with this organism (Forfar et al., 1953; Baldwin et al., 1957; Plueckhahn and Banks, 1958; Stenderup et al., 1959). However as recently as 1961-63 $\beta$-haemolytic streptococci 
TABLE I

Some Bacteria Responsible for Serious Perinatal Infection

\begin{tabular}{|c|c|}
\hline Organisms & References \\
\hline Achromobacter * & $\begin{array}{l}\text { Bernheim et al., 1959; Foley et al., } \\
1961\end{array}$ \\
\hline Aerobacter ${ }^{\star}$ & $\begin{array}{l}\text { Watson, 1957; Urmenyi and Franklin, } \\
1961\end{array}$ \\
\hline Alcaligenes faecalis ${ }^{\star}$ & $\begin{array}{l}\text { Sherman et al., 1960; Doxiadis } \\
\text { Pavlatou, and Chryssostomidou, } \\
1960\end{array}$ \\
\hline $\begin{array}{l}\text { Brucella abortus } \\
\text { Clostridium welchii }\end{array}$ & $\begin{array}{l}\text { Hagebusch and Frei, } 1941 \\
\text { Freedman and Hollander, } 1967\end{array}$ \\
\hline $\begin{array}{l}\text { Corynebacterium diphtheriae } \\
\text { Edwardsiella tarda }\end{array}$ & $\begin{array}{l}\text { Signy and Bruce, } 1932 \\
\text { Okubadejo and Alausa, } 1968\end{array}$ \\
\hline Escherichia coli & Craig, 1936; Kenny et al., 1966 \\
\hline $\begin{array}{l}\text { Flavobacterium meningo } \\
\text { septicum }\end{array}$ & $\begin{array}{l}\text { King, 1959; Cabrera and Davis, } \\
\text { 1961; George, Cochran, and } \\
\text { Wheeler, } 1961\end{array}$ \\
\hline Fusobacterium (Bacteroides) & $\begin{array}{l}\text { Robinow and Simonelli, 1965; } \\
\text { Pearson and Anderson, } 1967\end{array}$ \\
\hline Haemophilus influenzae & $\begin{array}{l}\text { Donald and Coker, 1957; Mathies, } \\
\text { Hodgman, and Ivler, 1965; } \\
\text { Ingman, } 1970\end{array}$ \\
\hline Klebsiella & Berant and Kahana, 1969 \\
\hline Listeria mon & $\begin{array}{l}\text { Seeliger, } 1961 \text {; Dungal, } 1961 \text {; } \\
\quad \text { Nelson, Shelton, and Parks, } 1967\end{array}$ \\
\hline Mimeae & de Torregrosa and Ortiz, 1961 \\
\hline Mycobacterium tuberculosis & Rich, 1951 \\
\hline Neisseria gonorrhoea & Smith, 1969 \\
\hline Neisseria meningitidis & Stiehm and Damrosch, 1966 \\
\hline 'Paracolon' & $\begin{array}{l}\text { Rance et al., 1962; Groover et al., } \\
\quad 1961\end{array}$ \\
\hline $\begin{array}{l}\text { Pasteurella multocida } \\
\text { (septica) }\end{array}$ & Bates et al., 1965 \\
\hline Pneumococcus & $\begin{array}{l}\text { Craig, 1936; Watson, 1957; Keitel } \\
\text { et al., } 1962\end{array}$ \\
\hline Proteus Spp. & $\begin{array}{c}\text { Becker, 1962; Cussen and Ryan, } \\
\text { 1967; Shortland-Webb, } 1968\end{array}$ \\
\hline Pseudomonas aeruginos $a^{\star}$ & $\begin{array}{l}\text { Rubbo et al., 1966; Jellard and } \\
\text { Churcher, } 1967\end{array}$ \\
\hline Salmonellae Spp. & $\begin{array}{l}\text { Abroms et al., 1966; Rowe et al., } \\
1969\end{array}$ \\
\hline Serratia marcescens & $\begin{array}{l}\text { Nelms et al., 1968; Ragazzini, } \\
\text { La Cauza and Ferrucci, } 1965\end{array}$ \\
\hline $\begin{array}{l}\text { Shigellae Spp. } \\
\text { Staphylococcus albus }\end{array}$ & $\begin{array}{l}\text { Salzman et al., 1967; Haltalin, } 1967 \\
\text { Buetow et al., } 1965\end{array}$ \\
\hline Staphylococcus aureus & $\begin{array}{l}\text { Forfar et al., 1953; Beaven and } \\
\text { Burry, } 1956\end{array}$ \\
\hline$\beta$-haemolytic streptococcus & $\begin{array}{l}\text { Dunham, 1933; Boissard and Eton, } \\
1956\end{array}$ \\
\hline $\begin{array}{l}\text { Streptococcus faecalis } \\
\text { Streptococcus viridans } \\
\text { Vibrio fetus }\end{array}$ & $\begin{array}{l}\text { McCracken and Shinefield, } 1966 \\
\text { Craig, 1936 } \\
\text { Eden, 1966; Willis and Austin, } 1966\end{array}$ \\
\hline
\end{tabular}

$\star$ Flourish in water.

were the most frequent single cause of neonatal sepsis at the Boston City Hospital, accounting for $25 \%$ of such infections (Eickboff et al., 1964), and were causing outbreaks of infection elsewhere (Nash, Mann, and Haydu, 1965).

A determined onslaught against the staphylococcus included such measures as 'rooming-in' for mothers and babies (Mortimer, Wolinsky, and Hines, 1966), air-conditioning, ultraviolet light, elaborate barrier nursing (Lancet, 1959), nasal creams (Jennison and Komrower, 1961), and the use of triple dye (Manfield, Shooter, and Lidwell, 1960) or occlusive dressings (Huntingford et al., 1961) for the umbilicus, but the application of hexachlorophane to the skin of infants, and to the hands of attendants appeared to be the most effective, resulting in a significant fall of nasal carriage of staphylococci by hospital newborns (Simpson, Tozer, and Gillespie, 1960; Plueckhahn, 1961; Simon, Yaffe, and Gluck, 1961) and of maternal breast abscess (Plueckhahn and Banks, 1964). Gupta, Roberton, and Wigglesworth (1968) showed that the daily application of polybactrin to the umbilicus in addition resulted in a greater degree of cord sterility. While nasal staphylococcal carriage rates of $80 \%$ were not infrequent in the first weeks of life, these have fallen as low as 4 to $6 \%$ in some nurseries (Williams and Oliver, 1969; Davies et al., 1970). However, even this cause and effect relation may be less than clear cut. Lowbury, Lilly, and Bull (1964a) point out that Semmelweis' historic success in controlling puerperal fever was more likely to have been due to vigorous physical ablution with its important action of removing desquamated epithelium, than to antiseptics. It would be imprudent too to think of the streptococcal and staphylococcal retreat as permanent; they may well be hovering virulently in the wings, ready to recapture the centre of the stage, for in the absence of control procedures, incidence has been very variable (Gezon, 1968). Even their temporary demise cannot be celebrated with too much acclaim, for in their place Gram-negative organisms, which were probably always present in certain categories of ill and low birthweight babies, now predominate in many newborn nurseries (Light et al., 1968; Forfar, Gould, and Maccabe, 1968), and give equal if not greater cause for anxiety.

This recent prominence of Gram-negative bacilli is mirrored in other hospital wards where ill patients are nursed (Watt and Okubadejo, 1967; Gallus, Stratford, and Dixson, 1969; Johanson, Pierce, and Sanford, 1969), and some of the reasons thought relevant for the newborn may be generally applicable. As already stated, the humidifying units of the specialized equipment which now surrounds the sick baby are known to harbour and propagate these organisms, frequently antibiotic resistant, unless the utmost care is taken with their cleansing. The majority of neonatal deaths used to occur in the first 24 hours after birth, but regardless of the eventual outcome, the use of modern therapeutic procedures such as mechanical ventilation means that intensive care nurseries are continually occupied with a higher number of seriously ill babies who act as a reservoir of bacteria contaminating 
their environment. The same is true of older children and adults who live longer with chronic debilitating disease. The lowered incidence of breast-feeding and excessive use of antibiotics may also contribute to Gram-negative ascendancy. Finally, but perhaps most important of all, the hands that remove soiled napkins and bedding with their predominantly Gram-negative flora are those that feed and minister. The newborn is now being handled, examined, and recorded as never before, and it should not surprise us that opportunities for contamination are greater, for scrupulousness in hand washing and in "no touch" techniques is difficult to achieve. Those who work in special care nurseries should have the same understanding of the facts of aseptic technique and the same close attention to practical detail as those in operating theatres.

\section{Clinical Diagnosis of Infection}

The emphasis in clinical diagnosis must surely be on very early detection, before damaging localization to organs has occurred. A fairly recent survey of neonatal meningitis reported a $60 \%$ mortality from most large series, with a high proportion of the survivors showing serious neurological sequelae (Haggerty and Ziai, 1964). The evidence reviewed by Smallpeice (1968) leaves little doubt that pyelonephritis acquired very early in life may seriously interfere with normal maturation and growth of the kidneys; and neonatal osteomyelitis, though rarely fatal, can still carry a poor functional prognosis (Lindblad, Ekengren, and Aurelius, 1965). Thus, there seems little to be gained by an exhaustive description of all the possible infections that can afflict the newborn. Many of them are listed in Table II, and one or more references given for those who wish further information.

Janeway (1966) has suggested that response to infection in the neonatal period is governed by the fact that the host is meeting bacterial antigens for the first time, and draws a parallel with primary and secondary tuberculosis. Regardless of the behaviour of humoral and cellular defence mechanisms, the newborn baby certainly presents to the clinician as one with a limited number of stereotyped responses to all manner of insults, and it should not surprise us that the early signs of infection listed by many observers are vague and non-specific. Subtle changes in behaviour, such as lessened activity and lethargic sucking, are early signs and nurses should be made aware of the importance of reporting them. Other features such as episodes of cyanosis and apnoea, failure to gain weight, abdominal distension, jaundice, hepatosplenomegaly, and enlarged kidneys
TABLE II

Some Perinatal Infections

\begin{tabular}{|c|c|}
\hline Infection & References \\
\hline \multirow{5}{*}{$\begin{array}{c}\text { Abscesses } \\
\text { Adrenal } \\
\text { Cerebral } \\
\text { Epidural } \\
\text { Liver } \\
\text { Palmar }\end{array}$} & \\
\hline & $\begin{array}{l}\text { Favara, Akers, and Franciosi, } 1970 \\
\text { Butler, Barrie, and Paine, } 1957\end{array}$ \\
\hline & Aicardi and Lepintre, 1967 \\
\hline & Dehner and Kissane, 1969 \\
\hline & $\begin{array}{l}\text { De Lorimier, Haskin, and Massie, } \\
1966\end{array}$ \\
\hline Parotid & Elterich, 1933 \\
\hline Prostatic & $\begin{array}{l}\text { Williams and Martins, 1960; Mann, } \\
1960\end{array}$ \\
\hline Retroperitoneal & $\begin{array}{l}\text { Grunwaldt and Tomsovic, 1957; } \\
\text { Lipsitz, } 1960\end{array}$ \\
\hline Scalp & $\begin{array}{l}\text { MacCarthy, Walker, and Matthews, } \\
1952\end{array}$ \\
\hline Endocarditis & $\begin{array}{l}\text { Lewis, 1954; Kunstadter and } \\
\text { Kaltenekker, } 1962\end{array}$ \\
\hline Gastro-enteritis & $\begin{array}{l}\text { Laurell et al., 1951; Rowe et al., } \\
\quad 1969\end{array}$ \\
\hline $\begin{array}{l}\text { Mastitis } \\
\text { Meningitis }\end{array}$ & $\begin{array}{l}\text { Schaffer, 1960; Stetler et al., } 1970 \\
\text { Watson, 1957; Groover et al., 1961; } \\
\text { Haggerty and Ziai, 1964; Berman } \\
\text { and Banker, } 1966\end{array}$ \\
\hline Necrotizing enterocolitis & $\begin{array}{l}\text { Mizrahi et al., 1965; Touloukian } \\
\text { et al., 1967; Stevenson et al., } 1969\end{array}$ \\
\hline $\begin{array}{l}\text { Omphalitis } \\
\text { Orchitis }\end{array}$ & $\begin{array}{l}\text { Forshall, 1957; Schaffer, } 1960 \\
\text { McCartney and Stewart, } 1958\end{array}$ \\
\hline Osteomyelitis & $\begin{array}{l}\text { Cavanagh, 1960; Neligan and } \\
\text { Elderkin, 1965; Lindblad et al., } \\
1965\end{array}$ \\
\hline Otitis media & Victorin, 1967 \\
\hline Pericarditis & $\begin{array}{l}\text { Valdes-Dapena and Miller, 1955; } \\
\text { Gersony and McCracken, } 1967\end{array}$ \\
\hline Peritonitis & $\begin{array}{l}\text { Beaven, 1958; Fonkalsrud, Ellis, and } \\
\text { Clatworthy, } 1966\end{array}$ \\
\hline Pneumonia & Bernstein and Wang, 1961 \\
\hline Pyelonephritis & $\begin{array}{l}\text { Porter and Giles, 1956; Kenny et al., } \\
1966\end{array}$ \\
\hline Septicaemia & $\begin{array}{l}\text { Dunham, 1933; Nyhan and Fousek, } \\
\text { 1958; Moorman and Sell, 1961; } \\
\text { Buetow et al., } 1965\end{array}$ \\
\hline Skin sepsis & Lee et al., 1952 \\
\hline
\end{tabular}

For details of pathology refer to the texts of Macgregor (1960), Potter (1961), and Morison (1963).

are among those presented most commonly (Cameron, 1929; Dunham, 1933; Nelson, 1960; Groover, Sutherland, and Landing, 1961; Nyhan and Fousek, 1958; Buetow, Klein, and Lane, 1965). It has been pointed out by Moncrieff (1953) that many infants in the first days of life have a rectal temperature of $36 \cdot 1{ }^{\circ} \mathrm{C}$, rather than the more usual adult norm of $37.2{ }^{\circ} \mathrm{C}$, and that a rise during this time may well be overlooked because of this. $\mathrm{He}$ also emphasized that overwhelming infection may be associated with a subnormal temperature. Regarding so-called 'dehydration fever' in the newborn period, Davis, Harvey, and Stevens (1966) state that while infection cannot be excluded in febrile infants where the plasma osmolality is raised, a normal osmolality with fever would make infection very likely.

Those most at risk from bacterial infection are 
essentially infants of low birthweight, and particularly the immature; males; those with congenital anomalies; and those born after prolonged membrane rupture or a protracted and difficult labour and delivery (Dunham, 1933; Nyhan and Fousek, 1958). Infants who are ill in the immediate postnatal period with such conditions as severe birth asphyxia and respiratory distress may be more likely to become infected. A proportion of immature infants may develop a functional ileus in the first days of life, and as stasis of intestinal contents is known to lead to bacterial overgrowth in the gut lumen (Hicks, Baumann, and Enquist, 1969), this could predispose to infiltration of the bowel mucosa and bacteraemia. The increased permeability of mucous membranes in the neonatal period has been cited by Vahlquist (1960).

The umbilicus as a site of direct access to the blood-stream must never be overlooked, and its proximity to the perineum may be one of the more important reasons for the frequency of Gramnegative infections such as coliform meningitis in the early weeks of life. Quite apart from the risk of blood-stream spread however, the untreated cord provides an excellent culture medium for organisms of all types, and they may be disseminated to other body surfaces, and contaminate the nurses' hands. Midline dermal sinuses, skin and mucosal abrasions or other wounds sustained during a difficult birth may also offer a portal of entry. Catheters cannulating vessels, umbilical or other, may themselves be a source of contamination (Howie and Cumming, 1962; Darrell and Garrod, 1969), and endotracheal tubes present for any length of time may predispose to ulceration of the mucosa. A small number of infants, presumably those who have received an overwhelming innoculum of bacteria in their passage through the birth canal or from contaminated equipment used in their treatment immediately after birth, may present with abnormal signs very early in their course. As already stated it is possible for such infants to die within $\mathbf{4 8}$ hours of birth, and it may well be that the most vigorous treatment has little to offer them. The diagnosis should be easiest when the infant deteriorates after a period of well-being.

Every effort should be made to recover infecting organisms before treatment is begun, and, if infection is suspected, swabs from nose, throat, umbilicus, and rectum, and any superficial area of sepsis should be taken. If any delay is likely before they can be plated out, they should be put into Stuart's transport medium (Stuart, 1959) on collection. In nearly all cases, the CSF and urine should be examined and cultured, and blood drawn for culture, total and differential white cell count, and immunoglobulin determination.

\section{Ancillary Aids to Diagnosis}

There is no rapid reliable test which can be used to diagnose infection in the neonatal period, and it is rarely if ever possible to wait for the results of cultures before starting treatment. Brief mention will be made of the uses and limitations of the various diagnostic tests.

White blood cells. After an initial rise, followed by a fall, the total neutrophil count stabilizes at 96 hours of age at a mean value of $4,100 / \mathrm{mm}^{3}$ with $\pm 2 \mathrm{SD}$ range of $1,400-6,900 \mathrm{~mm}^{3}$ in healthy infants (Xanthou, 1970). An increase in immature forms such as metamyelocytes and myelocytes, in band forms, and toxic granulation, and total neutrophil counts without the range given, may be suggestive of bacterial infection; and very ill and dying infants frequently have a marked neutropenia (M. Xanthou, unpublished data). Complete absence of leucocytes has been described by De Vaal and Seynhaeve (1959), and neutropenia or agranulocytosis present from birth may suggest either an inherited disorder, usually quickly fatal (Kostmann, 1956; MacGillivray et al., 1964) or a temporary condition associated with the formation of maternal leucocyte antibodies (Lalezari et al., 1960). These conditions may be associated with necrotic skin lesions. The NBT dye test may prove to have some application in diagnosis of infection if the preliminary findings of Cocchi et al. (1969) on a small number of infants are confirmed and extended.

Immunoglobulins. A cord blood value for IgM of greater than $20 \mathrm{mg} / 100 \mathrm{ml}$ is generally taken as indicating an immune response on the part of the fetus. Further investigations are needed to determine the cause. A rapid fall over the first days of life suggests a false positive, such as maternal bleeding into the fetal circulation (Sever, 1969). At the start of an infective illness a single determination is of little value, but if repeated after an interval of several days a sharp rise above the normal sequential increase would give retrospective confirmation of infection. Serum IgM levels in healthy infants for comparison during the first months of life are given by Blankenship et al. (1969). Infants dying of proven bacterial infection within the first 48 hours of life, whether acquired in the birth canal or after delivery, may do so with normal levels of serum IgM, presumably because there has not been time for them to muster an antibody response. 
C-reactive protein. This is not a reliable test as negative results have occurred in the presence of proven bacterial infection (P. A. Davies, M. J. Allington, and J. T. Hughes, unpublished data).

Blood culture. Whenever possible, samples should be drawn from peripheral veins, as those collected from umbilical vessel catheters may give false positive results (Johnston and Sell, 1964). Extra care must be taken over skin sterilization because of the technical difficulties of venepuncture in many infants. There may be difficulties in diagnosis if the amount of blood obtained is too small for more than one inoculation. In such cases where practicable every effort should be made to obtain another sample for separate inoculation. Eitzman and Smith (1957) felt that culture had to be positive in both flask and pour plates before they could be considered significant. More than one organism may invade the blood-stream simultaneously (Hochstein, Kirkham, and Young, 1965).

Swab cultures. Knowledge of the degree of colonization at the various sites is helpful, for bacterial infections are significantly more likely to occur when colonization is moderate or heavy (Gillespie et al., 1958; Davies et al., 1970).

Cerebrospinal fluid. It is essential to make a Gram stain of CSF, as bacteria may be present in the absence of pleocytosis at this age. Even the smallest or most blood-stained amount of CSF collected-if necessary the needle itself-should be sent for culture.

Urine. The collection of satisfactory urine specimens from the incontinent newborn with heavy bacterial contamination of the genital area has exercised many trying to establish normal standards for cell and bacterial counts at this age. In essence, methods range from a relatively timeconsuming one of the clean catch or mid-stream specimen, which requires personal supervision but no hazard to the infant (McCarthy and Pryles, 1963; Boehm and Haynes, 1966; Cruickshank and Edmond, 1967; Lirenman, 1969), through sterile tubes (McCarthy and Pryles, 1963) and collecting bags (Virtanen, Oksanen, and Peltonen, 1962; Masters and Lewis, 1965; Lam et al., 1967), to catheterization (McCarthy and Pryles, 1963) and suprapubic aspiration (Saccharow and Pryles, 1969). Perhaps nowhere should we ask ourselves more carefully where the true priorities in neonatal care lie.
The clean-catch method of Cruickshank and Edmond (1967) involves cleaning buttocks and perineum with soap and water (repeated after 20 minutes if no specimen appears), drying with a sterile swab, supporting the infant with thighs abducted, separating the labia but not retracting the foreskin, and collecting into a sterile container. Bacterial counts of $10^{4}$ organisms $/ \mathrm{ml}$ or less were obtained in $86 \%$, with $59 \%$ sterile. $96 \%$ of uncentrifuged well-shaken specimens contained fewer than 10 leucocytes $/ \mathrm{mm}^{3}$ in both sexes. Peroxidase positive stains (Prescott and Brodie, 1964) were used where necessary to differentiate renal tubular cells and leucocytes. Variation in the number and species of bacteria recovered between specimens from one patient suggested contamination rather than infection, but infection is likely when counts of $10^{5}$ organisms $/ \mathrm{ml}$ or more are isolated from 2 consecutive specimens.

There seems general agreement that urinary collecting bags whether sterile or unsterile (Lam et al., 1967) are less satisfactory as the number of false positives is too high (Virtanen et al., 1962; Masters and Lewis, 1965), and cell counts are significantly raised in female babies (Braude et al., 1967). However, using a complicated skin cleansing technique, a sterile tube, and generally meticulous approach, McCarthy and Pryles (1963) found $93 \%$ of specimens cultured less than $10^{5}$ organisms/ $\mathrm{ml}$. In older children a $97.5 \%$ diagnostic correlation was found between specimens obtained by catheter and suprapubic aspiration (Pryles et al., 1959) providing the first few $\mathrm{ml}$ of catheter urine were discarded. False positives were in the catheter group. For the very sick infant suprapubic aspiration is the best method, but failure rates of $8-10 \%$, the occurrence on occasions of haematuria (Saccharow and Pryles, 1969; Newman, O'Neill, and Parker, 1967), and perforation of abnormally enlarged viscera (Weathers and Wenzl, 1969) suggest that the widespread enthusiasm for this technique should be tempered with caution. The generally implicit assumption that a single suprapubic aspiration will settle the question incontrovertibly must be guarded against in view of the known intermittency of bacteriuria (Pryles, 1965).

The value of any collection, however made, will be invalidated by increase in bacterial number if the urine is kept at room temperature for more than 1 hour without being plated out; if plating out within this time proves impossible, refrigeration at $4{ }^{\circ} \mathrm{C}$, will prevent such multiplication for up to 48 hours (Kass, 1956). Stansfeld (1962) has shown that cells disappear very quickly in strongly alkaline urine. It is possible that the use of a dipslide system of 
bacterial culture may be found useful in simplifying the detection of bacteriuria in future (Arneil, McAllister, and Kay, 1970).

\section{Antibiotics. Treatment}

General consideration. It is essential that those prescribing drugs for the newborn be fully aware of his pharmacological peculiarities. A temporary deficit of certain enzymes and immature renal glomerular and tubular function lead both to inefficient detoxication of drugs by oxidative reduction, hydrolysis, and conjugation, and their impaired excretion by the kidney (Done, 1964). Other mechanisms may be contributory. The practical implication is that dosage schemes calculated on weight, surface area, or a percentage basis of the adult dose, which have been found suitable for older infants and children, have no place in the early neonatal period.

Some guide to antibiotic dosage and timing in the newborn has been given by recent studies on serum levels (Axline, Yaffe, and Simon, 1967; Boe et al., 1967; Abramowicz et al., 1966). The findings can be summarized by saying that in the first days of life serum levels are sustained for considerably longer than normal after a single dose. With increasing postnatal age, there is a gradual decline, but levels tend to be higher than those in older children and adults until the end of the first month. These findings are exaggerated in the premature who shows higher levels at any given age than the term infant. Serum half-lives three to five times those of adults were reported by some. Before these facts were fully appreciated many antibiotics were prescribed in inappropriate dosage, sometimes with lethal results, particularly in the immature. The majority of the toxic reactions which affected the newborn in varying ways are described by Done (1964). Suggested dosages for the various antibiotic drugs which take all this into account are given in Table III.

It had been supposed that bacteria became resistant to antibiotics only after exposure to them, but the discovery of transferable drug resistance 10 or so years ago in Japan and its subsequent recognition in Europe (Datta, 1962) shed new light on the problem which may have significance for the newborn. Genetic material transmitting resistance may be chromosomal or extra chromosomal. The former is non-transferable, the latter, consisting of genetic particles known as $R$-factors, is transferable by conjugation. Thus if two cultures, one of which contains R-factors, are mixed in vitro, the second acquires resistance within a very short time, and a similar transfer may go on in the bowel when
TABLE III

\section{Some Suggested Neonatal Dosages}

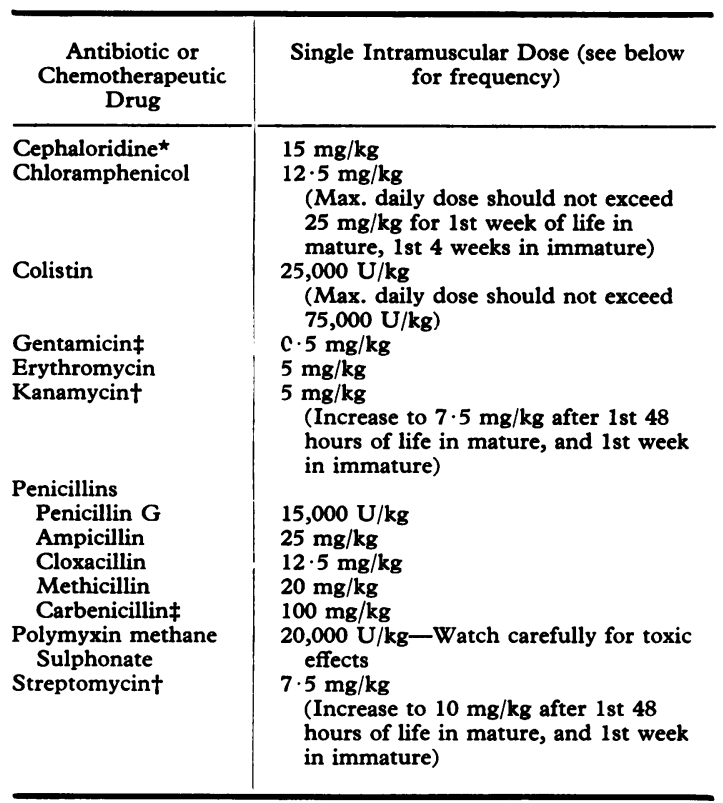

Frequency of Intramuscular Dose

For mature infants (more than 37 weeks' gestation) give above doses every 12 hours if in 1 st 48 hours of life, 8-hourly if between 3rd day and 2 weeks, and 6 hourly if over 2 weeks, unless otherwise indicated.

For immature infants (less than 37 weeks' gestation), give 12-hourly if in 1st week of life, 8-hourly if 1 to 4 weeks, and 6-hourly if over 4 weeks, unless otherwise indicated.

Note: No available guides to intravenous dosage based on serum levels - should probably not exceed two-thirds of the intramuscular dosage.

Note: Absorption from gastrointestinal tract may be uncertain during first week of life in mature and first two weeks of life in immature infants. Intramuscular dosage is therefore preferable during these periods.

^Need not be given more than 8 hourly at any age if I.M.

+ Need not be given more than 12 hourly at any age if I.M.

$\ddagger$ Published blood levels in newborn not yet available.

bacteria containing $\mathrm{R}$-factors are swallowed and come in contact with the normal bowel population (Datta, 1965). Outbreaks of gastroenteritis in small infants due to pathogens with multiple drug resistance have been reported (Salzman et al., 1967; Anderson, 1968).

Antibacterial drugs are undoubtedly greatly overprescribed in the neonatal period because fatal disease is common, clinical and laboratory evidence for infection uncertain, and the start of treatment cannot be delayed until results of cultures are known. In a six-month survey of their efficacy in a nursery dealing with ill and low birthweight infants, antibiotics were prescribed for $29 \%$ of the infants admitted. When all the evidence from ancillary investigations, cultures, and histology was later 
reviewed just over half of those treated were found to have evidence of bacterial infection (Davies et al., 1970). Other nurseries have reported using antibiotics at a rate of $50-60 \%$ (Shallard and Williams, 1966; Farmer, 1968). There is evidence that their widespread use may have brought about changes in bacterial flora and in the host himself, which have increased the opportunities for invasion by usually benign organisms, the majority of them Gramnegative (Finland, Jones, and Barnes, 1959). It seems that the restriction of their use whenever possible may reduce the likelihood of resistant strains appearing (Barber et al., 1960; Bulger and Sherris, 1968).

Choice of drugs. This must be governed to a large extent by knowledge of the current bacteriological flora of the newborn nursery, and of course of the individual infant if known in advance. Staff of maternity units in general hospitals must also be aware of predominant pathogens and antibiotic policy in the hospital as a whole.

In nurseries where Staphylococcus aureus is rarely seen, penicillin and kanamycin has proved a suitable combination, and after three years of its use the vast majority of Escherichia coli isolated from the infants in a special care nursery were still fully sensitive to kanamycin (Davies et al., 1970). Some have advocated the use of a single broad spectrum drug such as cephaloridine (Keay, Syme, and Barnes, 1967) and have suggested its inclusion in a scheme of rotation of drugs, since the longcontinued use of a single antibiotic leads eventually to the development of resistant organisms (Forfar et al., 1966). Some isolates of Escherichia coli resistant to cephaloridine were reported by Burland and Simpson (1967) during a trial of its use over an unspecified period in a newborn nursery. A combination of ampicillin and cloxacillin is frequently used, particularly in domiciliary practice, where it is possible Staphylococcus aureus may still be more evident than in many hospitals.

None of these antibacterial drugs is effective against Pseudomonas aeruginosa which in many nurseries proves difficult to dislodge, even when scrupulous care is taken over the cleansing of apparatus. The available antibiotics at present are polymyxin methane sulphonate, colistin, carbenicillin, and gentamicin. Polymyxin has proved disappointing in doses not exceeding $20,000 \mathrm{U} / \mathrm{kg}$ per day, for therapeutic serum levels are not reached (Davies et al., 1970) and H. F. Eichenwald (1967, personal communication) has advised that higher doses may be toxic. Carbenicillin seems the drug of choice, but reports of resistant strains are already appearing (Darrell and Waterworth, 1969; Bell and
Smith, 1969), and it should probably always be used in combination with gentamicin in view of the synergistic action reported (Brumfitt, Percival, and Leigh, 1967), or with polymyxin, and its use reserved only for proven cases of pseudomonas infection.

Indications for treatment. Any infant developing the vague non-specific signs already referred to as possibly indicating infection, particularly after a period of well-being, should be treated after appropriate swabs and specimens for culture have been taken. Antibiotic therapy is also justifiable for infants appearing ill at birth who are known to have come from an infected intrauterine environment, and for those with respiratory distress who show signs of deterioration. Superficial staphylocccal sepsis has often been considered an indication for systemic treatment in the past. Erythromycin (which cannot now be thought a useful single drug) reduced staphylococcal osteomyelitis and mortality rates in newborn nurseries when used for minor staphylococcal infections. Chloramphenicol however did not do so as effectively (Forfar et al., 1966), and the question must remain open.

While antibiotic treatment of gastroenteritis may be secondary in importance to the correction of electrolyte disturbances, appropriate drugs should not be withheld, because of the ease with which blood-stream invasion occurs in newborn and especially premature infants. Some value in drug treatment has been shown in controlled trials (Medical Research Council, 1953), as well as in prevention of cross-infection and relapse and stopping epidemics generally (Laurell et al., 1951; Stulberg et al., 1955; Valman and Wilmers, 1969), though the carrier state frequently persists and may be prolonged. The heavy environmental contamination at such times is conducive to spread (Rogers, 1951) unless nursing and medical techniques are of the most scrupulous.

Meningitis. In most published series Gramnegative organisms account for $70 \%$ of the cases. The systemic drugs of choice are therefore kanamycin, chloramphenicol, ampicillin, or gentamicin, and treatment should be intravenous in the first 24-48 hours. If kanamycin is used and Staphylococcus aureus is unlikely, crystalline penicillin $G$ should be added until confirmation is forthcoming. If Staphylococcus aureus is a probability, methicillin or cloxacillin will be essential, though methicillin resistance appears to be increasing (Ridley et al., 1970). Listeria monocytogenes is usually sensitive to ampicillin, penicillin, chloramphenicol, streptomycin, kanamycin, cephaloridine, and the tetracyclines (best avoided). Trimethoprim and sulphamethoxazole have been used successfully in 
an infant with Escherichia coli meningitis with loculated purulent CSF after failure of a battery of other antibiotic and chemotherapeutic drugs (Morzaria, Walton, and Pickering, 1969). If Pseudomonas aeruginosa is a possibility, polymyxin methane sulphonate should be added to kanamycin, and given by the intrathecal route at a dosage of $0.5-1.0 \mathrm{mg} /$ day, as well as by the systemic, because of poor diffusion. If infection with this organism is proven, carbenicillin with gentamicin or polymyxin is probably the most suitable combination. The use of intrathecal treatment in other cases is controversial and arguments for and against have been marshalled by Weinstein, Goldfield, and Adamis (1953), and Hoyne (1953); to these may be added the technical difficulties of repeated lumbar puncture in the very immature. Blood and CSF levels of antibiotic if available would be a helpful guide to the adequacy of treatment. Since active ventriculitis has been reported in the presence of acellular and sterile CSF (Berman and Banker, 1966), there might seem to be a place for intrathecal instillation of drugs, and Lorber (1967) believes this essential in treating meningitis in infants with meningomyelocele. However the danger of porencephalic cyst formation following ventricular puncture (Lorber, 1968) suggests this route should be avoided if at all possible. Single intrathecal doses for kanamycin and gentamicin are 1.0 and $0.5 \mathrm{mg}$ respectively, higher levels often being necessary in meningomyelocele when hydrocephalus is present.* Systemic treatment should be continued for a minimum of three weeks.

Although the use of steroids has been advocated in the treatment of neonatal meningitis ( $\mathrm{Yu}$ and Grauaug, 1963), study of adrenal function in children with meningitis (Migeon et al., 1967) and controlled trials in children over the age of 1 month, suggest they are not helpful (deLemos and Haggerty, 1969).

Urinary infection. Unless congenital anomaly of the urinary tract is present, urinary infections, being more often blood-borne, show less tendency to relapse than at older ages (Smallpeice, 1968). Smallpiece recommends nevertheless a minimum of six weeks' treatment. The sulphonamides are probably the drugs of choice unless the infection occurs in the first week or so of life, when risk of sulphonamide displacing bilirubin from protein-binding sites exists (Silverman et al., 1956). Kanamycin would be a suitable alternative during this period, unless Pseudomonas aeruginosa is the cause. Nalidixic acid should not be used for the newborn (Kemball and Davies, 1967).

\footnotetext{
*See also Lorber, Kalhan, and Mahgrefte (1970).
}

Osteomyelitis. The majority of recently reported cases were still caused by Staphylococcus aureus (Winters and Cahen, 1960; Gilmour, 1962), but bone lesions due to haemolytic streptococci, and to common and uncommon Gram-negative bacilli have been described (Nelms et al., 1968), and the latter may assume greater importance now. Where staphylococcal infection is probable, methicillin or cloxacillin are the initial drugs of choice, though until final culture results are available, an additional drug active against Gram-negative organisms would be wise. There is some controversy over the length of treatment necessary. Dennison (1955) recommends that it should not continue once the blood infection appears to be controlled, while Bremner and Neligan (1958) advocate a minimum of 3 weeks, and often treat for a longer period. These authors also state that aspiration of pus through a wide bore needle, repeated several times if necessary, is now preferable to open operation in the newborn.

Other supportive therapy. Small blood transfusions may be of value in treatment of serious neonatal infection. Apart from correcting the occasional obvious anaemia seen in some coliform infections (Dunham, 1933), the transfused blood may enhance the host's defence mechanisms by providing polymorphonuclear leucocytes and serum opsonins. Bactericidal activity in stored bank blood is greatest in the 24 hours after collection, and completely lost after 4 days (McCullough et al., 1969), so that only fresh blood should be used. Intravascular coagulation may occur in overwhelming sepsis, but the most effective treatment will be that of the infection itself.

Hyponatraemia has been reported in septicaemia and meningitis in older children (Nyhan and Cooke, 1956) and may need correction. Severe hypernatraemia and metabolic acidosis occur frequently with gastroenteritis, and the urgent correction of these electrolyte disturbances and dehydration is essential. Endotoxin shock as a concomitant of serious Gram-negative infections in older children is well recognized, and may be accompanied by metabolic acidosis and hypoglycaemia (Hodes, 1969). A similar situation may be present in the newborn, and these conditions in any event are well-recognized complications in infants of low birthweight suffering from non-infective disease, but in infections they may need to be specifically sought and treated if present.

\section{Prevention of Infection}

A clean house. One of the most disturbing aspects of newborn care in recent years has been 
the frequency with which outbreaks of sepsis have been traced to contaminated equipment. It is probable that many other such episodes have gone unrecorded, or even unrecognized, for unless a diligent search for infection is made in ill babies, and necropsies performed on all who die, the extent of the problem may not be appreciated. A summary of some of the more important aspects of cleaning wards and equipment is given in the Appendix.

'Barrier' nursing techniques. Forfar and Maccabe (1958) showed in a small controlled trial that the use of masks and gowns by nursery staff affected neither staphylococcal carriage rates nor infective illness in the infants, but did tend to keep the doctors away. (Opinion polls on whether this was a good or bad thing would be interesting.) Silverman and Sinclair (1967) devised a 2-year trial divided into 2-month periods, in which handwashing only before touching a baby, and gowning reserved for infants not in incubators, were alternated with traditional techniques, and were unable to show any advantage for the more elaborate rituals. Williams and Oliver (1969), after a 2-year period of using standard techniques introduced sequential changes over the next 4 years, such as stopping the use of caps, gowns for incubator infants, masks, hairnets, nail brushes, and entranceto-nursery handwashing, as well as allowing parents and medical students access to the infants, all apparently without mishap. Certainly many of the feelings of inadequacy on the mother's part when total responsibility for a low birthweight infant is delegated to her abruptly on discharge can be lessened if she has been allowed to participate in care from an early stage, and the banning of parents from newborn nurseries is to be heartily condemned.

Sequential trials such as those mentioned above are open to criticism in that strict controls of other variables which may influence mortality, such as rate of non-infective illness and the general work load of the nursery, is not possible, and these may influence rates of bacterial infection. Nevertheless, at the risk of being repetitious, it does seem that effective handwashing is the sheet anchor of defence against the spread of infection in nurseries, and should be practised obsessionally. Hexachlorophane (3\%) as a liquid soap or cream, active against Grampositive bacteria, and aqueous chlorhexidine $(0.5 \%)$, active against $\mathrm{Gram}$-negative, both have a cumulative effect when used for handwashing and rinsing, respectively (Lowbury, Lilly, and Bull, 1964b). Needless to say Psuedomonas aeruginosa has been isolated from both these substances and careful attention must be paid to the sterilization of the dispensing containers (Medical Research Council, 1968). The wearing of disposable gloves should further reduce hand contamination.

Antibiotic prophylaxis. Smith, Jennison, and Langley (1956) considered that fetal infection was likely in the presence of a persistent fetal tachycardia of $160 /$ minute or above, and a maternal temperature of $37{ }^{\circ} \mathrm{C}$ or above in labour. They claimed a reduction in infant deaths from infection when such mothers were treated with streptomycin and oxytetracycline for $\mathbf{4 8}$ hours or more before delivery. The fetal infection to which they refer is pneumonia and there must be some doubt as to whether this represents genuine infection or aspiration in association with fetal hypoxia (see above). Their numbers also were small, birthweight and gestation were not mentioned, and in a later communication (Langley and Smith, 1959) they felt unable to say that perinatal mortality was reduced. The fact that low birthweight and prolonged membrane rupture are correlated make this a difficult question to answer without a large controlled trial. Lebherz et al. (1963) gave demethylchortetracycline to mothers with premature rupture of the membranes, and, in a double-blind study involving 1896 women, were unable to show any significant effect on perinatal mortality. It seems unlikely, unless maternal bacteraemia is present, which is a rare occurrence according to Robinson et al. (1965), that antibiotics to the mother will influence perinatal mortality from infection to any great extent.

The same can almost certainly be said of the prophylactic administration of such drugs to infants born after prolonged membrane rupture. Though advocated (Bound, Butler, and Spector, 1956; Anderson et al. 1962), controlled trials have still to show its efficacy (Lebherz, Boyce, and Huston, 1961). The antibiotics penicillin and streptomycin given from birth delayed bacterial colonization at nose, throat, and umbilicus, but the organisms which emerged later did not differ significantly from untreated controls (Oh et al., 1964). While theoretically it sounds attractive to have these sites sterile during the first days of postnatal life when morbidity is at its height, the available evidence at present suggests antibiotic prophylaxis should be withheld from the great majority of infants who emerge from an apparently infected environment, reserving immediate treatment for those of them who appear ill at birth. Cultures of infected liquor or the placenta at delivery may prove helpful later if the infant should become ill. There is no clear evidence that antibiotic prophylaxis is necessary in respiratory 
distress, or to cover exchange transfusions.

The recent increase in gonorrhoea, which Smith (1969) has shown may be greatest in the inner zone of a large city and among the pregnant unmarried, has raised the question of whether chemoprophylaxis of ophthalmia neonatorum, abandoned in many maternity units, should be reintroduced. Neisseria gonorrhoeae was the commonest cause of purulent conjunctivitis in Glasgow infants between 1963 and 1968. Barsam (1966) reviewed United States experience and practice, and concluded that the continued routine use of $1 \%$ silver nitrate, which he considered safe if 'properly packaged, handled and administrated', was a necessary prophylactic measure.

Immunoglobulin administration. The possible suppression of the infant's own immune response by passively acquired antibody discussed earlier, and the later appearance of isoantibodies which might have implications for future blood transfusion or pregnancy (Smith, 1966) suggest that administration of immunoglobulin in the neonatal period is unjustified. Previous trials have not been satisfactory enough to suggest unequivocal benefit (Amer et al., 1963; Hodes, 1963; Carey, 1964), and commercial $\gamma$-globulin largely consists of IgG, of which the mature infant at least has a plentiful supply.

Artificial bacterial colonization. The deliberate introduction of a non-virulent strain of a coagulase-positive staphylococcus to the nose and umbilicus shortly after birth has been used by Shinefield et al. (1963) to colonize the infant with an organism that repels invasion by more virulent strains which have been causing infection. The finding by Davies et al. (1970) that infection occurred less often in infants heavily colonized with Gram-positive and mixed bacteria than in those colonized with Gram-negative bacteria, might also lend support to this venture in nurseries where heavy Gram-negative colonization is predominant. However, multiple infections reported recently due to the supposedly non-virulent staphylococci introduced in this way (Blair and Tull, 1969), suggest a limited use for this technique, though the similar practice of feeding lactobacilli to infants with gastroenteritis is well established (Davidson, 1966).

Care of infant's skin and umbilicus. The washing of the newborn's skin with hexachlorophane (3\%) has already been referred to as an effective measure in reducing staphylococcal colonization. Since the umbilicus represents a direct portal of entry to the blood-stream, efforts to keep it as sterile as possible seem justified, particularly if the umbilical vessels are to be cannulated. Polybactrin spray at birth, and daily until the cord separates largely achieves this (Gupta et al., 1968; Davies et al., 1970). If local antibiotics are not used, an occlusive dressing though it will not prevent colonization (Huntingford et al., 1961) seems preferable to no dressing at all, in view of the proximity of the perineum with its heavy bacterial contamination.

Regular surveillance of flora. Ideally regular swabbings of newborn infants should be made to identify current flora in newborn nurseries. Thus any concentration of unusual pathogens such as Pseudomonas aeruginosa which are not normally present in healthy infants can be detected. Any infections should be carefully recorded, and more than one serious infection caused by a single organism within a short space of time should be regarded as an epidemic and the nursery closed. The source of infection must be identified by making relevant cultures of all the other infants, the staff, the environment, and the infants' mothers if necessary. All too often these measures are not introduced early enough in newborn nurseries, with the result that infection is protracted and may lead to serious mortality and morbidity.

Milk kitchens. Many hospital nurseries may be in process of changing from conventional terminal sterilization of feeds to ready-to-use products or aseptically prepared feeds in disposable bottles. In whatever way feeds are made bacteriologically innocuous, there are still opportunities for contamination during distribution and even feeding if strict aseptic techniques are not observed.

It is well known that hypochlorite solutions may be inactivated by organic matter such as milk residue, and even when cleansing of equipment was conscientiously carried out, Ayliffe, Collins, and Pettit (1970) were able to show contamination of feeds in a milk kitchen using this method of disinfection because taps of a mixing container could not be effectively cleansed first. They believe the method is not suitable for hospital use.

\section{Conclusions}

The great majority of infants survive the perinatal period without developing, much less succumbing to, bacterial infection. Defence mechanisms develop steadily from early in intrauterine life, and at birth the mature infant of a healthy mother is well equipped to withstand the relatively minor infective hazards of passage through her birth canal. During 
this process he has his first encounter with bacteria, and the colonization of various sites in his body by these organisms and those of a relatively clean postnatal environment may be considered part of normal developmental physiology, and of ultimate benefit to him.

A mother with bacterial infection may transmit it to her fetus. Maternal bacteraemia can lead to fetal bacteraemia; bacilli may ascend from the vagina through ruptured membranes to the uterine cavity; or be encountered in large numbers in the vagina during delivery. If the infant is born prematurely, and particularly if male, his defence mechanisms are less well developed, and during the activity directed at keeping him alive, he may undergo much handling. Exposure to special equipment may be necessary to resuscitate him at birth, clear his airways, maintain his temperature, and even artificially ventilate his lungs. Unless great conscientiousness is shown by his attendants, both their hands and the equipment they manipulate may be a source of infection. Since he is unable to concentrate inflammatory cells selectively and since he cannot always kill bacteria effectively, there may be widespread dissemination of infection.

Gram-negative organisms have always constituted a threat to the newborn, mainly because of the proximity of umbilical wound and perineum, but with the control of the streptococcus and staphylococcus they now assume greater importance, and bowel organisms have been joined by those flourishing in the humidification units of equipment. Our aim must be to prevent infection by keeping his environment as bacteriologically clean as possible, for if the rapidly growing organs of this period of life are invaded by bacteria the damage caused may strikingly impair their ultimate size and function. This is to be achieved more by a high standard of household and hand cleanliness than the widespread use of antibiotics, for these may alter the balance of flora and encourage resistant organisms.

I am grateful to Professor J. P. M. Tizard, Dr. J. H. Darrell, and Dr. J. S. Wigglesworth for helpful advice and criticism. I should also like to acknowledge my debt to Dr. Victoria Smallpeice, who first stimulated my interest in this subject, and impressed me with the importance of preventing damage by infection to rapidly growing organs.

\section{Appendix}

The environment of special care nurseries is likely to be more heavily contaminated with bacteria than other hospital wards (Shallard and Williams, 1965). Dirt and organic matter may inactivate many chemical disinfectants and the main emphasis should be on really efficient cleansing procedures (Public Health Laboratory Service Committee, 1965). The provision of adequate space in newborn nurseries while secondary in importance to aseptic techniques, does make their practice easier; storage room should be provided for equipment not in current use.

Cleaning of floors and surfaces. The bacteria found in dust are predominantly Gram-positive, though Gram-negative organisms survive there too, and mopping floors with soap and water will merely spread them evenly, whereas cleansing with an effective phenolic disinfectant such as Sudol 1 in 100 removes $99 \%$ of them, though for a relatively short time, and only if protected from dust shed by shoes. Dry dusting and sweeping may release huge numbers of bacteria into the air, and dust should ideally be removed by properly filtered vacuum suction dusters (Ayliffe, Collins, and Lowbury, 1966; British Medical Journal, 1968). Bacteria may survive for long periods between loose floor tiles (Rogers, 1963) but are disseminated less easily from waxed surfaces (British Medical Journal, 1968).

Disinfection of equipment. The special equipment increasingly surrounding the sick newborn is only safe from the bacterial contamination which may cause lethal disease when utmost conscientiousness is shown in its cleansing. This dull work usually falls entirely on the nursing staff and they should be constantly encouraged by explanations of its importance.

Incubators. Humidification units should be emptied daily and refilled with boiling water. As an extra precaution the unit may be flushed with $0.25 \%$ acetic before refilling. If not in use treat similarly, or dry out by keeping machine switched on for 24 hours after draining. Cleansing of incubators should be carried out by washing all parts with warm soapy water inside and out and wiping with Milton hypochlorite solution $1: 80$. Plastic 'sleeves' of older models should be washed with warm soapy water and steeped in Milton $1: 80$ for up to 1 hour. Between use by individual infants machines should be returned to the surgical equipment store for more intensive cleansing with removal of power units, old filters, and fumigation. Though virtually no antiseptic is proof against Pseudomonas aeruginosa, this routine, a modification of that described by Barrie (1965), has been found effective in keeping these machines free from bacterial contamination in a busy neonatal ward.

Rubber or plastic tubing associated with incubators, oxygen equipment and suction apparatus, and Woolf's bottles should be boiled or autoclaved daily. Infant face masks should be boiled or autoclaved after use by each infant.

Lung ventilators-during prolonged mechanical ventilation bacterial contamination is common and has been a source of cross-infection. There is as yet no definite agreement on the best way of sterilizing the more complex machines (Lancet, 1968; Spencer et al., 1968; Judd et al., 1968). A small solenoid-activated valve ventilator used for the newborn (Grausz, Watt, and Becket, 1967) can be autoclaved. 
Disinfectant solutions. Most disinfectants have been found contaminated with Gram-negative bacilli, particularly Pseudomonas aeruginosa. Benzalkonium chloride (Roccal), phenol (Carbolic acid), cetrimide (Cetavlon), and chloroxylenol (Dettol) are best avoided as their antibacterial properties are limited and they support bacterial growth more easily.

Bottles of stock disinfectants should never be closed with bark corks for these contain substances which may inactivate the antiseptics. Similarly bark bungs and cork liners in screw caps should not be used (Lancet, 1968).

Correspondence to Dr. Pamela A. Davies, The Neonatal Research Unit, Hammersmith Hospital, London, W.12.

\section{REFERENCES}

Abramowicz, M., Klein, J. O., Ingall, D., and Finland, M. (1966). Levels of penicillin in serum of newborn infants. American fournal of Diseases of Children, 111, 267.

Abroms, I. F., Cochran, W. D., Holmes, L. B., Marsh, E. B., and Moore, J. W. (1966). A Salmonella newport outbreak in a premature nursery with a one-year follow-up. Effect of ampicillin following bacteriologic failure of response to kanamycin. Pediatrics, 37, 616

Adinolfi, M., and Gardner, B. (1967). Synthesis of $\beta_{1 \mathrm{E}}$ and $\beta_{1 \mathrm{C}}$ components of complement in human foetuses. Acta Paediatrica Scandinavica, 56, 450.

- - - and Wood, C. B. S. (1968). Ontogenesis of two components of human complement: $\beta_{1 \mathrm{E}}$ and $\beta_{1 C}-1 \mathrm{~A}$ globulins. Nature (London), 219, 189.

- Glynn, A. A., Lindsay, M., and Milne, C. M. (1966). Serological properties of $\gamma \mathrm{A}$ antibodies to Escherichia coli present in human colostrum. Immunology, 10, 517.

$\longrightarrow$, and Wood, C. B. S. (1969). Ontogenesis of immunoglobulins and components of complement in man. In Immunology and Development (Clinics in Developmental Medicine No. 34), p. 27. Ed. by M. Adinolfi and J. Humphrey, Heinemann, London.

Aherne, W., and Davies, P. A. (1962). Congenital pneumonia. (Letter to Editor). Lancet, 1, 275.

Aicardi, J., and Lepintre, J. (1967). Spinal epidural abscess in a 1-month-old child. American fournal of Diseases of Children, $114,665$.

Allan, R. N., and Alexander, M. K. (1968). A sex difference in the leucocyte count. Fournal of Clinical Pathology, 21, 691.

Amer, J., Ott, E., Ibbott, F. A.. O'Brien, D., and Kempe, C. H. (1963). The effect of monthly gamma-globulin administration on morbidity and mortality from infection in premature infants during the first year of life. Pediatrics, 32, 4.

American fournal of Diseases of Children (1961). Water bugs in the bassinet. (Editorial). 101, 273.

Anderson, E. S. (1968). Middlesbrough outbreak of infantile enteritis and transferable drug resistance. British Medical fournal, 1, 293.

Anderson, G. S., Green, C. A., Neligan, G. A., Newell, D. J., and Russell, J. K. (1962). Congenital bacterial pneumonia. Lancet, 2, 585 .

Arneil, G. C., McAllister, T. A., and Kay, P. (1970). Detection of bacteriuria at room-temperature. Lancet, 1, 119.

Axline, S. G., Yaffe, S. J., and Simon, H. J. (1967). Clinical pharmacology of antimicrobials in premature infants. II. Ampicillin, methicillin, oxacillin, neomycin, and colistin. Pediatrics, 39, 97.

Ayliffe, G. A. J., Collins, B. J., and Lowbury, E. J. L. (1966). Cleaning and disinfection of hospital floors. British Medical fournal, 2, 442.

- - Lowbury, E. J. L., Babb, J. R., and Lilly, H. A. (1967). Ward floors and other surfaces as reservoirs of hospital infection. fournal of Hygiene, 65, 515.

- and Pettit, F. (1970). Contamination of infant feeds Milton milk kitchen. Lancet, 1, 559.

Baehner, R. L., Karnovsky, M. J., and Karnovsky, M. L. (1969). Degranulation of leukocytes in chronic granulomatous disease. fournal of Clinical Investigation, 48, 187.
- , and Nathan, D. G. (1967). Leukocyte oxidase: Defective activity in chronic granulomatous disease. Science, 155, 835.

Balassanian, N., and Wolinsky, E. (1968). Epidemiologic and serologic studies of $E$. coli $04: \mathrm{H} 5$ in a premature nursery. Pediatrics, 41, 463.

Baldwin, J. N., Rheins, M. S., Sylvester, R. F., Jr., and Shaffer, T. E. (1957). Staphylococcal infections in newborn infants. III. Colonization of newborn infants by Staphylococcus pyogenes. American Fournal of Diseases of Children, 94, 107.

Barber, M., Dutton, A. A. C., Beard, M. A., Elmes, P. C., and Williams, R. (1960). Reversal of antibiotic resistance in hospital staphylococcal infection. British Medical fournal, 1, 11.

- and Okubadejo, O. A. (1965). Maternal and neonatal listeriosis: report of case and brief review of literature of listeriosis in man. British Medical fournal, 2, 735.

Barbero, G. J., Runge, G., Fischer, D., Crawford, M. N., Torres, F. E., and György, P. (1952). Investigations on the bacterial flora, $\mathrm{pH}$, and sugar content in the intestinal tract of infants. Fournal of Pediatrics, 40, 152.

Barrie, D. (1965). Incubator-borne Pseudomonas pyocyanea infection in a newborn nursery. Archives of Disease in Childhood, 40, 555.

Barsam, P. C. (1966). Specific prophylaxis of gonorrheal ophthalmia neonatorum. New England fournal of Medicine, 274, 731.

Bassett, D. C. J., Thompson, S. A. S., and Page, B. (1965). Neonatal infections with Pseudomonas aeruginosa associated with contaminated resuscitation equipment. Lancet, 1, 781.

Bates, H. A., Controni, G., Elliott, N., and Eitzman, D. V. (1965) Septicemia and meningitis in a newborn due to Pasteurella multocida. Clinical Pediatrics, 4, 668.

Beaven, D. W. (1958). Staphylococcal peritonitis in the newborn. Lancet, 1, 869.

- and Burry, A. F. (1956). Staphylococcal pneumonia in the newborn. An epidemic with 8 fatal cases. Lancet, 2, 211.

Becker, A. H. (1962). Infection due to Proteus mirabilis in newborn nursery. American fournal of Diseases of Children, 104, 355.

Bell, S. M., and Smith, D. D. (1969). Resistance of Pseudomonas aeruginosa to carbenicillin. Lancet, 1, 753.

Benirschke, K. (1960). Routes and types of infection in the fetus and the newborn. American fournal of Diseases of Children, 99, 714.

- and Clifford, S. H. (1959). Intrauterine bacterial infection of the newborn infant. Frozen sections of the cord as an aid to early detection. Fournal of Pediatrics, 54, 11 .

-, and Driscoll, S. G. (1967). The Pathology of the Human Placenta. Springer, Berlin and New York.

Benner, M. C. (1940). Congenital infection of the lungs, middle ears and nasal accessory sinuses. Archives of Pathology, 29, 455.

Berant, M., and Kahana, D. (1969). Klebsiella osteomyelitis in a newborn. American fournal of Diseases of Children, 118, 634.

Berg, T. (1968). Immunoglobulin levels in infants with low birth weights. Acta Paediatrica Scandinavica, 57, 369.

Berman, P. H., and Banker, B. Q. (1966). Neonatal meningitis. A clinical and pathological study of 29 cases. Paediatrics, 38, 6 .

Bernheim, M., Germain, D., Courtieu, A- L., and Nivelon, J- L. (1959). Les méningites purulentes néo-natales à Moraxella glucidolytica (Bacterium anitratum). Biologia Neonatorum, 1, 143.

Bernstein, J., and Wang, J. (1961). The pathology of neonatal pneumonia. American fournal of Diseases of Children, 101, 350.

Blair, E. B., and Tull, A. H. (1969). Multiple infections among newborns resultirg from colonization with Staphylococcus aureus 502A. American fournal of Clinical Pathology, 52, 42.

Blanc, W. A. (1959). Amniotic infection syndrome. Pathogenesis, morphology, and significance in circumnatal mortality. Clinical Obstetrics and Gynecology, 2, 705.

- (1961). Pathways of fetal and early neonatal infection. Viral placentitis, bacterial and fungal chorioamnionitis. Fournal of Pediatrics, 59, 473.

Blankenship, W. J., Cassady, G., Schaefer, J., Straumfjord, J. V., and Alford, C. A., Jr. (1969). Serum gamma-M globulin responses in acute neonatal infections and their diagnostic significance. Fournal of Pediatrics, 75, 1271.

Boe, R. W., Williams, C. P. S., Bennett, J. V., and Oliver, T. K., Jr. (1967). Serum levels of methicillin and ampicillin in newborn and premature infants in relation to postnatal age. Pediatrics, 39, 194. 
Boehm, J. J., and Haynes, J. L. (1966). Bacteriology of 'midstream catch' urines. Studies in newborn infants. American fournal of Diseases of Children, 111, 366.

Boissard, J. M., and Eton, B. (1956). Neonatal umbilicus as a source of streptococcal infections in a maternity unit. British Medical fournal, 2, 574.

Bound, J. P., Butler, N. R., and Spector, W. G. (1956). Classification and causes of perinatal mortality. British Medical fournal, 2, 1191, 1260.

Bourne, G. L. (1962). The Human Amnion and Chorion. LloydLuke, London.

Braude, H., Forfar, J. O., Gould, J. C., and McLeod, J. W. (1967). Cell and bacterial counts in the urine of normal infants and children. British Medical fournal, 4, 697.

Bremner, A. E., and Neligan, G. A. (1958). Pyogenic osteitis. In Recent Advances in Paediatrics, 2 nd ed. p. 354 by D. M. T. Gairdner. Churchill, London.

Brewer, D. B. (1963). Electron microscopy of phagocytosis of staphylococci. Fournal of Pathology and Bacteriology, 86, 299.

British Medical fournal (1960). Masks or silence. (Leading article). $1,1339$.

(1968). Bacteria in the hospital environment. (Leading article). 3,200 .

Brody, J. I., and Oski, F. (1967). Immunologic memory of the normal and the leukemic lymphocyte. Annals of Internal Medicine, 67, 573.

Browne, F. J. (1922). Discussion on still births and neo-natal deaths. IV. Neo-natal deaths. British Medical fournal, $2,590$.

Brumfitt, W., Percival, A., and Leigh, D. A. (1967). Clinical and laboratory studies with carbenicillin. Lancet, 1, 1289.

Bryant, R. E., Windom, R. E., Vineyard, J. P., Jr., and Sanford, J. P. (1964). Asyptomatic bacteriuria in pregnancy and its association with prematurity. Forunal of Laboratory and Clinical Medicine, 63, 224.

Buetow, K. C., Klein, S. W., and Lane, R. B. (1965). Septicemia in premature infants. American fournal of Diseases in Children, $110,29$.

Bulger, R. J., and Sherris, J. C. (1968). Decreased incidence of antibiotic resistance among Staphylococcus aureus. A study in a university hospital over a 9-year period. Annals of Internal Medicine, 69, 1099.

Bullock, J. D., Robertson, A. F., Bodenbender, J. G., Kontras, S. B., and Miller, C. E. (1969). Inflammatory response in the neonate re-examined. Pediatrics, 44, 58.

Burland, W. L., and Simpson, K. (1967). Administration of cephaloridine to the newborn infant. Postgraduate Medical fournal, 43, Aug. Suppl., 112.

Butler, N. R., Barrie, H., and Paine, K. W. E. (1957). Cerebral abscess as a complication of neonatal sepsis. Archives of Disease in Childhood, 32, 461.

Butterworth, M., McClellan, B., and Allansmith, M. (1967). Influence of sex on immunoglobulin levels. Nature (London), 214, 1224.

Cabrera, H. A., and Davis, G. H. (1961). Epidemic meningitis of the newborn caused by flavobacteria. I. Epidemiology and bacteriology. American fournal of Diseases of Children, 101, 289.

Cameron, H. C. (1929). Some types of septic infection in the newlyborn (Ingleby Lectures). Lancet, 1, 1127, 1184.

Carey, D. E. (1964). Gamma-globulin for premature infants. Pediatrics, 33, 466.

Cavanagh, F. (1960). Osteomyelitis of the superior maxilla in infants. A report on 24 personally treated cases. British Medical fournal, 1, 468.

Claireaux, A. E. (1958). Neonatal pathology. In Modern Trends in Paediatrics. Second series, p. 52. Ed. by A. Holzel and J. P. M. Tizard. Butterworth, London.

Cline, M. J. (1965). Metabolism of the circulating leukocyte. Physiological Reviews, 45, 674.

Cocchi, P., and Marianelli, L. (1967). Phagocytosis and intracellular killing of Pseudomonas aeruginosa in premature infants. Helvetica Paediatrica Acta, 22, 110.

Cocchi, P., Mori, S., and Becattini, A. (1969). N.B.T. tests in premature infants. Lancet, $2,1426$.

Coen, R., Grush, O., and Kauder, E. (1969). Studies of bactericidal activity and metabolism of the leukocyte in full-term neonates. Fournal of Pediatrics, 75, 400.

Cohen, I. R., and Norins, L. C. (1968). Antibodies of the IgG, IgM, and IgA classes in newborn and adult sera reactive with gram-negative bacteria. Fournal of Clinical Investigation, 47, 1053.

Cohn, Z. A., and Hirsch, J. G. (1960). The isolation and properties of the specific cytoplasmic granules of rabbit polymorphonuclear leucocytes. Fournal of Experimental Medicine, 112, 983.

Colebrook, L., and Kenny, M. (1936). Treatment with Prontosil of puerperal infections due to haemolytic streptococci. Lancet, 2, 1319.

Cooper, M. L., Keller, H. M., Walters, E. W., Partin, J. C., and Boye, D. E. (1959). Isolation of enteropathogenic Escherichio coli from mothers and newborn infants. American fournal of Diseases of Children, 97, 255.

Craig, W. S. (1936). Meningitis in the newborn. Archives of Disease in Childhood, 11, 171.

Crosby, R. M. N., Mosberg, W. H., Jr., and Smith, G. W. (1951). Intra-uterine meningitis as a cause of hydrocephalus. fournal of Pediatrics, 39, 94

Cruickshank, G., and Edmond, E. (1967). 'Clean catch' urines in the newborn: bacteriology and cell excretion patterns in firs week of life. British Medical fournal, 4, 705.

Cussen, L. J., and Ryan, G. B. (1967). Hemorrhagic cerebral necrosis in neonatal infants with enterobacterial meningitis. fournal of Pediatrics, 71, 771 .

Darrell, J. H., Farrell, B. C., and Mulligan, R. A. (1967). Case of human vibriosis. British Medical fournal, 2, 287.

, and Garrod, L. P. (1969). Secondary septicaemia from intravenous cannulae. British Medical fournal, 2, 481.

, and Waterworth, P. M. (1969). Carbenicillin resistance in Pseudomonas aeruginosa from clinical material. British Medical fournal, 3, 141.

Datta, N. (1962). Transmissible drug resistance in an epidemic strain of Salmonella typhimurium. fournal of Hygiene, 60, 301. (1965). Infectious drug resistance. British Medical Bulletin, 21, 254.

Davidson, M. (1966). Nonspecific diarrhea. In Current Pediatric Therapy. Ed. by S. S. Gellis and B. M. Kagan. Saunders, Philadelphia and London.

Davies, P. A. (1965). Congenital pneumonia. Clinical Pediatrics, $4,523$.

, and Aherne, W. (1962). Congenital pneumonia. Archives of Disease in Childhood, 37, 598.

- Darrell, J. H., Chandran, K. R., and Waterworth, P. M. (1970). The efficacy of antibiotics in the neonatal period. In The Control of Chemotherapy, p. 49. Ed. by P. J. Watt. Livingstone, Edinburgh and London.

Davies, R. R., and Noble, W. C. (1962). Dispersal of bacteria on desquamated skin. Lancet, 2, 1295.

Davis, J. A., Harvey, D. R., and Stevens, J. F. (1966). Osmolality as a measure of dehydration in the neonatal period. Archives of Disease in Childhood, 41, 448.

Dehner, L. P., and Kissane, J. M. (1969). Pyogenic hepatic abscess in infancy and childhood. fournal of Pediatrics, 74, 763.

deLemos, R. A., and Haggerty, R. J. (1969). Corticosteroids as an adjunct to treatment in bacterial meningitis. A controlled clinical trial. Pediatrics, 44, 30.

De Lorimier, A. A., Haskin, D., and Massie, F. S. (1966). Mediastinal mass caused by vertebral osteomyelitis. American fournal of Diseases of Children, 111, 639.

Dennison, W. M. (1955). Haematogenous osteitis in the newborn. Lancet, 2, 474.

Derrington, M. M., and Soothill, J. F. (1961). An immunochemical study of the proteins of amniotic fluid and of maternal and foetal serum. Fournal of Obstetrics and Gynaecology of the British Commonwealth, 68, 755.

de Torregrosa, M., and Ortiz, A. (1961). Severe infections in children due to rare gram-negative bacilli. (Mima polymorpha and Bacillus anitratum). Fournal of Pediatrics, 59, 35.

De Vaal, O. M., and Seynhaeve, V. (1959). Reticular dysgenesia. Lancet, 2, 1123.

Dixon, H. G., and Brant, H. A. (1967). The significance of bacteriuria in pregnancy. Lancet, $1,19$.

Donald, W. D., and Coker, J. W. (1957). The role of Hemophilus influenzae in respiratory infections of premature infants. American fournal of Diseases of Children, 94, 272.

Done, A. K. (1964). Developmental pharmacology. Clinical Pharmacology and Therapeutics, 5, 432.

Dossett, J. H., Williams, R. C., Jr., and Quie, P. G. (1969). Studies on interaction of bacteria, serum factors and polymorphonuclear leukocytes in mothers and newborns. Pediatrics, 44, 49. 
Doxiadis, S. A., Pavlatou, M., and Chryssostomidou, O. (1960). Bacillus faecalis alcaligenes septicemia in the newborn. fournal of Pediatrics, 56, 648.

Dungal, N. (1961). Listeriosis in four siblings. Lancet, 2, 513.

Dunham, E. C. (1933). Septicemia in the new-born. American fournal of Diseases of Children, 45, 229.

Eden, A. N. (1966). Perinatal mortality caused by Vibrio fetus. fournal of Pediatrics, 68, 297.

Edwards, M. S., Griffiths, L. L., and Swift, P. N. (1958). Cellular immunity at birth. The mechanism and nature of the phagocytic response. Archives of Disease in Childhood, 33, 512.

Eichenwald, H. F., Kotsevalov, O., and Fasso, L. A. (1960). The 'cloud baby': an example of bacterial-viral interaction. American Fournal of Diseases of Children, 100, 161.

Eickhoff, T. C., Klein, J. O., Daly, A. K., Ingall, D., and Finland, M. (1964). Neonatal sepsis and other infections due to Group B beta-hemolytic streptococci. New England fournal of Medicine, 271, 1221.

Eitzman, D. V., and Smith, R. T. (1957). The significance of blood cultures in the newborn period. American fournal of Diseases of Children, 94, 601.

- and - (1959). The nonspecific inflammatory cycle in the neonatal infant. American fournal of Diseases of Children, 97, 326.

Elias-Jones, T. F., Gordon, I., and Whittaker, L. (1961). Staphylococcal infection of the newborn in hospital and in domiciliary practice. Lancet, 1,571 .

Elterich, T. O. (1933). Purulent parotitis in the newborn. Case report and review of the literature. Fournal of Pediatrics, 3,761 .

Ensign, P. R., and Hunter, C. A. (1946). An epidemic of diarrhea in the newborn nursery caused by a milk-borne epidemic in the community. Fournal of Pediatrics, 29, 620.

Farmer, K. (1968). The influence of hospital environment and antibiotics on the bacterial flora of the upper respiratory tract of the newborn. New Zealand Medical Fournal, 67, 541.

Favara, B. E., Akers, D. R., and Franciosi, R. A. (1970). Adrenal abscess in a neonate. Fournal of Pediatrics, 77, 682.

Felix, N. S., Nakajima, H., and Kagan, B. M. (1966). Serum Creactive protein in infections during the first six months of life. Pediatrics, 37, 270

Felton, D. J. C., and Williams, J. D. (1967). Prophylactic ampicillin in the surgical induction of labour. Fournal of Obstetrics and Gynaecology of the British Commonwealth, 74, 862.

Fierer, J., Taylor, P. M., and Gezon, H. M. (1967). Pseudomonas aeruginosa epidemic traced to delivery-room resuscitators. New England fcurnal of Medicine, 276, 991.

Finland, M., Jones, W. F., Jr., and Barnes, M. W. (1959). Occurrence of serious bacterial infections since introduction of antibacterial agents. Fournal of the American Medical Association, 170, 2188.

Fireman, P., Zuchowski, D. A., and Taylor, P. M. (1969). Development of human complement system. Fournal of Immunology, $103,25$.

Fishel, C. W., and Pearlman, D. S. (1961). Complement components of paired mother-cord sera. Proceedings of the Society for Experimental Biology and Medicine, 107, 695.

Florman, A. L., and Teubner, D. (1969). Enhancement of bacterial growth in amniotic fluid by meconium. Fournal of Pediatrics, $74,111$.

Foley, J. F., Gravelle, C. R., Englehard, W. E., and Chin, T. D. Y. (1961). Achromobacter septicemia-fatalities in prematures. I. Clinical and epidemiological study. American fournal of Diseases of Children, 101, 279.

Fonkalsrud, E. W., Ellis, D. G., and Clatworthy, H. W., Jr. (1966). Neonatal peritonitis. fournal of Pediatric Surgery, 1, 227.

Forfar, J. O., Balf, C. L., Elias-Jones, T. F., and Edmunds, P. N. (1953). Staphylococcal infection of the newborn. British Medical fournal, 2, 170.

- Gould, J. C., and Maccabe, A. F. (1968). Effect of hexachlorophane on incidence of staphylococcal and gram-negative infection in the newborn. Lancet, $2,177$.

-, Keay, A. J., Maccabe, A. F., Gould, J. C., and Bain, A. D. (1966). Liberal use of antibiotics and its effect in neonatal staphylococcal infection, with particular reference to erythromycin. Lancet, 2, 295.

-, and Maccabe, A. F. (1958). Masking and gowning in nurseries for the newborn infant. Effect on staphylococcal carriage and infection. British Medical fournal, 1, 76.
Forshall, I. (1957). Septic umbilical arteritis. Archives of Disease in Childhood, 32, 25.

Frappier-Davignon, L., Frappier, A., and St.-Pierre, J. (1959). Staphylococcal infection in hospital nurseries. Influence of three different nursing techniques. Canadian Medical Association fournal, 81, 531 .

Freedman, S., and Hollander, M. (1967). Clostridium perfringens septicemia as a postoperative complication of the newborn infant. Fournal of Pediatrics, 71, 576.

Freund, J. (1931). Reaction of young and adult rabbits to pneumococci injected into the skin. Fournal of Experimental Medicine, $54,171$.

Fujikura, T., and Froehlich, L. A. (1967). Intrauterine pneumonia in relation to birth weight and race. American fournal of Obstetrics and Gynecology, 97, 81.

Gairdner, D. M. T. (1954). The care of the newborn infant. In Recent Advances in Paediatrics. Ed. by D. M. T. Gairdner. p. 87. Churchill, London.

Galask, R. P., and Snyder, I. S. (1968). Bacterial inhibition by amniotic fluid. American fournal of Obstetrics and Gynecology, $102,949$.

- and - (1970). Antimicrobial factors in amniotic fluid. American fournal of Obstetrics and Gynecology, 106, 59.

Gallus, A. S., Stratford, B. C., and Dixson, S. (1969). Alteration of superficial bacterial flora in severely ill patients. Part I. Medical fournal of Australia, 2, 139.

Ganrot, P. O., and Kindmark, C. O. (1969). C-reactive protein-A phagocytosis-promoting factor. Scandinavian fournal of Clinical and Laboratory Investigation, 24, 215.

George, R. M., Cochran, C. P., and Wheeler, W. E. (1961). Epidemic meningitis of the newborn caused by Flavobacteria. II. Clinical manifestations and treatment. American fournal of Diseases of Children, 101, 296.

Gersony, W. M., and McCracken, G. H., Jr. (1967). Purulent pericarditis in infancy. Pediatrics, 40, 224.

Gezon, H. M. (1968). Diagnosis and treatment : adult staphylococcal nasal carriers in the newborn nursery. Pediatrics, 42, 353.

Gillespie, W. A., Simpson, K., and Tozer, R. C. (1958). Staphylococcal infection in a maternity hospital. Epidemiology and control. Lancet, $2,1075$.

Gilmour, W. N. (1962). Acute haematogenous osteomyelitis. fournal of Bone and foint Surgery, 44B, 841.

Gitlin, D., Rosen, F. S., and Michael, J. G. (1963). Transient 19S gamma 1 -globulin deficiency in the newborn infant, and its significance. Pediatrics, 31, 197.

Gluck, L., and Silverman, W. A. (1957). Phagocytosis in premature infants. Pediatrics, 20, 951.

Glynn, A. A. (1968). Lysozyme: antigen, enzyme and antibacterial agent. Scientific Basis of Medicine Annual Reviews, 31. , Martin, W., and Adinolfi, M. (1970). Levels of lysozyme in human foetuses and newborns. Nature (London), 225, 77.

Goodman, J. R., and Moore, R. E. (1956). Electron microscopic study of phagocytosis of staphylococcus by human leukocytes. fournal of Bacteriology, 71, 547.

Gower, P. E., Husband, P., Coleman, J. C., and Snodgrass, G. J. A. I. (1970). Urinary infection in two selected neonatal populations. Archives of Disease in Cildhood, 45, 259.

Grausz, J. P., Watt, N. L., and Becket, A. J. (1967). A new positivepressure respirator for newborns. Lancet, 2, 499.

Groover, R. V., Sutherland, J. M., and Landing, B. H. (1961). Purulent meningitis of newborn infants. Eleven-year experience in the antibiotic era. New England fournal of Medicine, 264, 1115.

Grüneberg, R. N., Leigh, D. A., and Brumfitt, W. (1969). Relationship of bacteriuria in pregnancy to acute pyelonephritis, prematurity, and fetal maturity. Lancet, $2,1$.

Grunwaldt, E., and Tomsovic, E. J. (1957). Iliac vein obstruction caused by retroperitoneal abscess in newborn infants. Review of the literature and report of two cases. Fournal of Pediatrics, 50,361 .

Grush, O. C., and Mauer, A. M. (1969). Neurophil function and N.B.T. dye reduction. Lancet, $2,383$.

Gupta, J. M., Roberton, N. R. C., and Wigglesworth, J. S. (1968). Umbilical artery catheterization in the newborn. Archives of Disease in Childhood, 43, 382.

Gusdon, J. P., Jr. (1969). Fetal and maternal immunoglobulin levels during pregnancy. American fournal of Obstetrics and Gynecology .103, 895. 
Hagebusch, O. E., and Frei, C. F. (1941). Undulant fever in children. American fournal of Clinical Pathology, 11, 497.

Haggerty, R. J., and Ziai, M. (1964). Acute bacterial meningitis. Advances in Pediatrics, 13, 129.

Haltalin, K. C. (1967). Neonatal shigellosis. Report of 16 cases and review of the literature. American fournal of Diseasse of Children, 114, 603.

Hardy, J. B., McCracken, G. H., Jr., Mellits, E. D., Gilkeson, M. R., and Sever, J. L. (1969). Serum immunoglobulin levels in newborn infants. III. Some preliminary observations from a survey of cord blood levels in 2,600 infants. Fournal of Pediatrics, 75, 1211.

Hare, R., and Ridley, M. (1958). Further studies on the transmission of Staph. aureus. British Medical fournal, 1, 69.

-, and Thomas, C. G. A. (1956). The transmission of Staphylococcus aureus. British Medical fournal, 2, 840.

Haworth, J. C., and Dilling, L. (1966). Concentration of $\gamma$ Aglobulin in serum, saliva and nasopharyngeal secretions of infants and children. fournal of Laboratory and Clinical Medicine, 67, 922.

Henderson, A., Maclaurin, J., and Scott, J. M. (1969). Pseudomonas in a Glasgow baby unit. Lancet, 2, 316.

Hicks, C., Baumann, F. G., and Enquist, I. F. (1969). Changes in intestinal flora in dogs with nonstrangulating intestinal obstruction. Surgery, 66, 580.

Hicks, H. T., and French, H. (1905). Typhoid fever and pregnancy, with special reference to foetal infection. Lancet, 1, 1491.

Hirsch, J. G., and Cohn, Z. A. (1960). Degranulation of polymorphonuclear leucocytes following phagocytosis of microorganisms. Fournal of Experimental Medicine, 112, 1005.

Hobbs, J. R., and Davis, J. A. (1967). Serum $\gamma$ G-globulin levels and gestational age in premature babies. Lancet, 1, 757.

- Hughes, M. I., and Walker, W. (1968). Immunoglobulin levels in infants after intrauterine transfusion. Lancet, $1,1400$.

Hochstein, H. D., Kirkham, W. R., and Young, V. M. (1965). Recovery of more than 1 organism in septicemias. New England fournal of Medicine, 273, 468.

Hodes, H. L. (1963). Should the premature infant receive gammaglobulin? Pediatrics, 32, 1.

(1969). Care of the critically ill child: endotoxin shock. Pediatrics, 44, 248.

Holmes, B., Page, A. R., and Good, R. A. (1967). Studies of the metabolic activity of leukocytes from patients with a genetic abnormality of phagocytic function. Fournal of Clinical Investigation, 46, 1422.

-, Quie, P. G., Windhorst, D. B., and Good, R. A. (1966). Fatal granulomatous disease of childhood. An inborn abnormality of phagocytic function. Lancet, 1, 1225 .

Hood, M., and Todd, J. M. (1960). Vibro fetus: a cause of human abortion. American fournal of Obstetrics and Gynecology, 80, 506.

Howie, J. G. R., and Cumming, R. L. C. (1962). The role of infection in transfusion thrombophlebitis. Lancet, $2,851$.

Hoyne, A. L. (1953). Acute purulent meningitis. Medical Clinics of North America, 37, 329.

Humbert, J. R., Kurtz, M. L., and Hathaway, W. E. (1970). Increased reduction of nitroblue tetrazolium by neutrophils of newborn infants. Pediatrics, 45, 125.

Huntingford, P. J., Welch, G., Glass, U., and Wetherley-Mein, G. (1961). The problem of the neonatal umbilicus and its relation to the incidence of sepsis in a maternity unit. Fournal of Obstetrics and Gynaecology of the British Commonwealth, 68, 179.

Hurst, V. (1960). Transmission of hospital staphylococci among newborn infants. II. Colonization of the skin and mucous membranes of the infants. Pediatrics, 25, 204.

Ingman, M. J. (1970). Neonatal Hemophilus influenzae septicemia. American fournal of Diseases of Children, 119, 66.

Janeway, C. A. (1966). The immunological system of the child. Development of immunity in the child. Archives of Disease in Childhood, 41, 358 .

Jellard, C. H., and Churcher, G. M. (1967). An outbreak of Pseudomonas aeruginosa (pyocyanea) infection in a premature baby unit, with observations on the intestinal carriage of Pseudomonas aeruginosa in the newborn. Fournal of Hygiene, 65, 219.

Jennison, R. F., and Komrower, G. M. (1961). Effect of an antibacterial nasal cream on nasal colonization and infection in the newborn. British Medical fournal, 1, 89.
Johanson, W. G., Pierce, A. K., and Sanford, J. P. (1969). Changing pharyngeal bacterial flora of hospitalized patients. New England fournal of Medicine, 281, 1137.

Johnson, W. C., and Meyer, J. R. (1925). A study of pneumonia in the stillborn and new-born. American fournal of Obstetrics and Gynecology, 8, 151 and 267.

Johnston, R. B., Jr., and Sell, S. H. (1964). Septicemia in infants and children. Pediatrics, 34, 473.

Judd, P. A., Tomlin, P. J., Whitby, J. L., Inglis, T. C. M., and Robinson, J. S. (1968). Disinfection of ventilators by ultrasonic nebulization. Lancet, 2, 1019.

Karnovsky, M. L. (1962). Metabolic basis of phagocytic activity. Physiological Reviews, 42, 143.

Kass, E. H. (1956). Asymptomatic infections of the urinary tract. Transactions of the Association of American Physicians, 69, 56.

(1962). Pyelonephritis and bacteriuria. A major problem in preventive medicine. Annals of Internal Medicine, 56, 46.

Keay, A. J., Syme, J., and Barnes, P. M. (1967). Cephaloridine in the treatment and prophylaxis of infection in the newborn. Postgraduate Medical fournal, 43, Aug. Suppl., 105.

Keitel, H. G., Hananian, J., Ting, R., Prince, L. N., and Randall, E. (1962). Meningitis in the newborn infant. Report of 3 cases in whom the same organisms (pneumococci and Group B streptococci) were recovered from the spinal fluid and the maternal cervix. Fournal of Pediatrics, 61, 39.

Kelsall, G. R. H., Barter, R. A., and Manessis, C. (1967). Prospective bacteriological studies in inflammation of the placenta cord and membranes. Fournal of Obstetrics and Gynaecology of the British Commonvealth, 74, 401.

Kemball, M. L., and Davies, P. A. (1967). Nalidixic acid for the newborn. British Medical fournal, 2, 310.

Kenny, J. F., Medearis, D. N., Jr., Klein, S. W., Drachman, R. H., and Gibson, L. E. (1966). An outbreak of urinary tract infections and septicemia due to Escherichia coli in male infants. Fournal of Pediatrics, 68, 530.

King, E. O. (1959). Studies on a group of previously unclassified bacteria associated with meningitis in infants. American fournal of Clinical Pathology, 31, 241.

Kohn, J. (1967). Pseudomonas infection in hospital. British Medical fournal, 4, 548.

Kostmann, R. (1956). Infantile genetic agranulocytosis (Agranulocytosis infantilis hereditaria). A new recessive lethal disease in man. Acta Paediatrica, 45, suppl. 105.

Kunstadter, R. H., and Kaltenekker, F. (1962). Acute verrucous endocarditis in the newborn. Fournal of Pediatrics, 61, 58.

Lalezari, P., Nussbaum, M., Gelman, S., and Spaet, T. H. (1960). Neonatal neutropenia due to maternal isoimmunization. Blood, 15, 236

Lam, C. N., Bremner, A. D., Maxwell, J. D., Murphy, A. V., and Low, W. J. (1967). Pyuria and bacteriuria. Archives of Disease in Childhood, 42, 275.

Lancet (1959). Staphylococcal disease in hospitals. (Leading article). 1, 185.

- (1968). Bacteria in the ward. (Leading article). 2, 1067.

Lang, K. (1955). Listeria-Infektion als mögliche Ursache früh erworbener Cerebralschäden. Zeitschrift fur Kinderheilkunde, 76, 328.

Langley, F. A., and Smith, J. A. McC. (1959). Perinatal pneumonia. A retrospective study. Fournal of Obstetrics and Gynaecology of the British Empire, 66, 12.

Laurell, G., Magnusson, J. H., Frisell, E., and Werner, B. (1951). Epidemic infantile diarrhea and vomiting. Acta Paediatrica, 40, 302.

Lebherz, T. B., Boyce, C. R., and Huston, J. W. (1961). Premature rupture of the membrane. A statistical study from 7 U.S. Navy hospitals. American fournal of Obstetrics and Gynecology, 81, 658.

, Hellman, L. P., Madding, R., Anctil, A., and Arje, S. L. (1963) Double-blind study of premature rupture of the membranes. American fournal of Obstetrics and Gynecology, 87, 218.

Lee, H. F., Wilson, R. B., Brown, C. E., and Reed, T. P. (1952). Impetigo and acute infectious exfoliative dermatitis of the newborn infant (Ritter's Disease). Fournal of Pediatrics, 41, 159.

Lewis, I. C. (1954). Bacterial endocarditis complicating septicaemia in an infant. Archives of Disease in Childhood, 29, 144.

Lide, T. N. (1947). Congenital tularemia. Archives of Pathology, 43, 165. 
Light, I. J., Sutherland, J. M., Cochran, M. L., and Sutorius, J. (1968). Ecologic relation between Staphylococcus aureus and pseudomonas in a nursery population. New England fournal of Medicine, 278, 1243.

Lind, T., and Hytten, F. E. (1969). Relation between birth-weight and rupture-delivery interval. Lancet, 1, 917.

Lindblad, B., Ekengren, K., and Aurelius, G. (1965). The prognosis of acute haematogenous osteomyelitis and its complications during early infancy after the advent of antibiotics. Acta Paediatrica Scandinavica, 54, 24.

Lipsitz, P. J. (1960). Iliac vein obstruction due to a retro-peritoneal abscess. Archives of Disease in Childhood, 35, 399.

-, and Cornet, J. M. (1960). Blood cultures from the umbilical vein in the newborn infant. Pediatrics, 26, 657.

Lirenman, D. S. (1969). Urinary tract infections in the newborn: diagnosis from mid-stream urine specimens. Canadian Medical Association fournal, 101, 664.

Lockwood, W. R., and Allison, F. (1963). Electron micrographic studies of phagocytic cells. I. Morphological changes of the cytoplasm and granules of rabbit granulocytes associated with ingestion of rough Pneumococcus. British fournal of Experimental Pathology, 44, 593.

Löfström, G. (1944). Comparison between the reactions of acute phase serum with Pneumococcus C-polysaccharide and with Pneumococcus type 27. British fournal of Experimental Patho$\log y, 25,21$.

Lorber, J. (1967). Intrathecal and intraventricular kanamycin in the treatment of meningitis and ventriculitis in infants. Postgraduate Medical fournal, 43, May suppl., 52.

(1968). Puncture porencephaly. Developmental Medicine and Child Neurology, 10, 233.

- Kalhan, S. C., and Mahgrefte, B. (1970). Treatment of ventriculitis with gentamicin and cloxacillin in infants born with spina bifida. Archives of Disease in Childhood, 45, 178.

Love, G. J., Gezon, H. M., Thompson, D. J., Rogers, K. D., and Hatch, T. F. (1963). Relation of intensity of staphylococcal infection in newborn infants to contamination of nurses' hands and surrounding environment. Pediatrics, 32, 956.

Lowbury, E. J. L., Lilly, H. A., and Bull, J. P. (1964a). Disinfection of hands: removal of transient organisms. British Medical fournal, 2, 230.

,-- , and Bull, J. P. (1964b). Methods for disinfection of hands and operation sites. British Medical fournal, 2, 531.

MacCarthy, D., Walker, A. H. C., and Matthews, S. (1952). Scalp abscess in the newborn. A discussion of their causation. fournal of Obstetrics and Gynaecology of the British Empire, $59,37$.

McCarthy, J. M., and Pryles, C. V. (1963). Clean voided and catheter neonatal urine specimens. Bacteriology in the male and female neonate. American fournal of Diseases of Children, 106, 473.

McCartney, E. T., and Stewart, I. (1958). Suppurative orchitis due to Pseudomonas aeruginosa. Fournal of Pediatrics, 52, 451.

McCracken, G. H., Jr., and Shinefield, H. R. (1966). Changes in the pattern of neonatal septicemia and meningitis. American fournal of Diseases of Children, 112, 33.

McCullough, J., Benson, S. J., Yunis, E. J., and Quie, P. G. (1969). Effect of blood-bank storage on leucocyte function. Lancet, 2 , 1333.

McFarlan, A. M., Crone, P. B., and Tee, G. H. (1949). Variations in bacteriology of throat and rectum of infants in two maternity units. British Medical fournal, 2, 1140.

MacGillivray, J. B., Dacie, J. V., Henry, J. R. K., Sacker, L. S., and Tizard, J. P. M. (1964). Congenital neutropenia: a report of five cases. Acta Paediatrica, 53, 188.

Macgregor, A. R. (1960). Pathology of Infancy and Childhood. Livingstone, Edinburgh and London.

McKay, E., and Thom, H. (1969). Observations on neonatal tears. fournal of Pediatrics, 75, 1245.

McKell, W. M., Helseth, H. K., and Brunson, J. G. (1960). Influence of endotoxin on the placental-fetal barrier. (Abstr.) Federation Proceedings, 19, 246.

Manfield, P. A., Shooter, R. A., and Lidwell, O. M. (1960). Nasal staphylococci and sepsis in newborn babies. British Medical fournal, 1, 1098.

Mann, S. (1960). Prostatic abscess in the newborn. Archives of Disease in Childhood, 35, 396.

Masters, P. L., and Lewis, I. C. (1965). Urinary infection in childhood. British Medical fournal, 1, 856.
Mathies, A. W., Jr., Hodgman, J., and Ivler, D. (1965). Hemophilus influenzae meningitis in a premature infant. Pediatrics, 35, 791.

Matoth, Y. (1952). Phagocytic and ameboid activities of the leukocytes in the newborn infant. Pediatrics, $9,748$.

Medical Research Council (1953). Antibiotic and chemotherapeutic agents in the treatment of infantile diarrhoea and vomiting. Lancet, 2, 1163.

(1967). Spread of hospital staphylococci in healthy families: a study from general practice. British Medical fournal, 4, 642 . (1968). Aseptic methods in the operating suite. Lancet, 1, 763.

Metchnikoff, E. (1893). Lectures on the Comparative Pathology of Inflammation. Kegan Paul, London.

Migeon, C. J., Kenny, F. M., Hung, W., and Voorhess, M. L. (1967). Study of adrenal function in children with meningitis. Pediatrics, 40, 163.

Miller, M. E. (1969). Phagocytosis in the newborn infant: humoral and cellular factors. Fournal of Pediatrics, 74, 255.

Mizrahi, A., Barlow, O., Berdon, W., Blanc, W. A., and Silverman, W. A. (1965). Necrotizing enterocolitis in premature infants. Fournal of Pediatrics, 66, 697.

Moncrieff, A. (1953). Infection in the newborn baby. British Medical fournal, $1,1$.

Moorman, R. S., Jr., and Sell, S. H. (1961). Neonatal septicemia. Southern Medical fournal, 54, 137.

Morison, J. E. (1963). Foetal and Neonatal Pathology, 2nd ed. Butterworth, London.

Morse, L. J., and Schonbeck, L. E. (1968). Hand lotions: a potential nosocomial hazard. New England fournal of Medicine, 278, 376.

Mortimer, E. A., Jr., Lipsitz, P. J., Wolinsky, E., Gonzaga, A. J., and Rammelkamp, C. H., Jr. (1962). Transmission of staphylococci between newborns. American fournal of Diseases of Children, 104, 289.

-, Wolinsky, E., and Hines, D. (1966). The effect of roomingin on the acquisition of hospital staphylococci by newborn infants. Pediatrics, 37, 605.

Morzaria, R. N., Walton, I. G., and Pickering, D. (1969). Neonatal meningitis treated with trimethoprim and sulphamethoxazole. British Medical fournal, 2, 511.

Müller-Eberhard, H. J. (1969). Complement. Annual Review of Biochemistry, 38, 389.

Nash, F. W., Mann, T. P., and Haydu, I. W. (1965). An outbreak of streptococcal infection in a maternity unit. Postgraduate Medical fournal, 41, 182.

Neligan, G. A., and Elderkin, F. M. (1965). Treatment of acute haematogenous osteitis in children assessed in a consecutive series of selected cases. British Medical fournal, 1, 1349.

Nelms, D. K., Goldman, A. S., O'Donell, A. A., and Henry, M. J. (1968). Serratia marcescens osteomyelitis in an infant. Fournal of Pediatrics, 72, 222.

Nelson, J. D., Shelton, S., and Parks, D. (1967). Antibiotic susceptibility of Listeria monocytogenes and treatment of neonatal listeriosis with ampicillin. Acta Paediatrica Scandinavica, 56, 151.

Nelson, W. E. (1960). On the role of infections in neonatal mortality. fournal of Pediatrics, 56, 274.

Nemir, R. L., Roberts, P. H., and Barry-LeDeaux, S. (1957). Observations of antistreptolysin-O, C-reactive protein and electrophoretic protein patterns in maternal and neonatal sera. fournal of Pediatrics, 51, 493.

Newman, C. G. H., O'Neill, P., and Parker, A. (1967). Pyuria in infancy, and the role of suprapubic aspiration of urine in diagnosis of infection of urinary tract. British Medical fournal, $2,277$.

Nyhan, W. L., and Cooke, R. E. (1956). Symptomatic hyponatremia in acute infections of the central nervous system. Pediatrics, 18, 604.

, and Fousek, M. D. (1958). Septicemia of the newborn. Pediatrics, 22, 268.

Oh, W., Keller, R., Klein, R. I., and Kunstadter, R. H. (1964). Antibiotics in infants for premature rupture of membranes. American fournal of Diseases of Children, 108, 149.

Okubadejo, O. A., and Alausa, K. O. (1968). Neonatal meningitis caused by Edwardsiella tarda. British Medical fournal, 3, 357.

Olding, L. (1966). Bacterial infection in cases of perinatal death. Acta Paediatrica Scandinavica, 56, suppl. 171. 
Osborn, G. R. (1958). Discussion on neonatal deaths: secondary causes of death in the foetus and newborn. Proceedings of the Royal Society of Medicine, 51, 840.

- (1962). Congenital pneumonia. Lancet, 1, 275.

Overbach, A. M., Daniel, S. J., and Cassady, G. (1970). The value of umbilical cord histology in the management of potential perinatal infection. Fournal of Pediatrics, 76, 22.

Park, B. H., Fikrig, S. M., and Smithwick, E. M. (1968). Infection and nitroblue-tetrazolium reduction by neutrophils. A diagnostic aid. Lancet, 2, 532.

- Holmes, B., and Good, R. A. (1970). Metabolic activities in leukocytes of newborn infants. Fournal of Pediatrics, 76, 237.

,-- , Rodey, G. E., and Good, R. A. (1969). Nitroblue tetrazolium test in children with fatal granulomatous disease and newborn infants. Lancet, 1, 157.

Patrick, M. J. (1967). Influence of maternal renal infection on the foetus and infant. Archives of Disease in Childhood, 42, 208.

Pearson, H. E., and Anderson, G. V. (1967). Perinatal deaths associated with Bacteroides infections. Obstetrics and Gyneco$\log y, 30,486$.

Phillips, I., and Spencer, G. (1965). Pseudomonas aeruginosa crossinfection due to contaminated respiratory apparatus. Lancet, 2, 1325.

Plueckhahn, V. D. (1961). The staphylococcus and the newborn child. British Medical fournal, 2, 779.

- - and Banks, J. (1958). The ubiquitous staphylococcus. Medical fournal of Australia, 1, 664.

- , and - (1964). Breast abscess and staphylococcal disease in a maternity hospital. British Medical fournal, 2, 414.

Porter, K. A., and Giles, H. McC. (1956). A pathological study of five cases of pyelonephritis in the newborn. Archives of Disease in Childhood, 31, 303.

Potter, E. L. (1961). Pathology of the Fetus and Infant, 2nd ed. Year Book Medical Publishers, Chicago.

Prescott, L. F., and Brodie, D. E. (1964). A simple differential stain for urinary sediment. Lancet, $2,940$.

Prindull, G. (1968). Cellular inflammatory reactions in newborns and older infants. Blut, 17, 279.

Pryles, C. V. (1965). Percutaneous bladder aspiration and other methods of urine collection for bacteriologic study. Pediatrics, 36, 128.

—, Atkin, M. D., Morse, T. S., and Welch, K. J. (1959). Comparative bacteriologic study of urine obtained from children by percutaneous suprapubic aspiration of the bladder and by catheter. Pediatrics, 24, 983.

Public Health Laboratory Service Committee (1965). Use of disinfectants in hospitals. British Medical fournal, 1, 408.

Quie, P. G., White, J. G., Holmes, B., Good, R. A. (1967). In vitro bactericidal capacity of human polymorphonuclear leukocytes: diminished activity in chronic granulomatous disease of childhood. Fournal of Clinical Investigation, 46, 668.

Ragazzini, F., La Cauza, C. and Ferrucci, M. (1965). Infection by Serratia marcescens in premature children. Annales Paediatrici, 205, 289.

Rance, C. P., Roy, T. E., Donohue, W. L., Sepp. A., Elder, R., and Finlayson, M. (1962). An epidemfc of septicemia with meningitis and hemorrhagic encephalitis in premature infants. Fournal of Pediatrics, 61, 24.

Rappaport, F., Rabinovitz, M., Toaff, R., and Krochik, N. (1960). Genital listeriosis as a cause of repeated abortion. Lancet, $1,1273$.

Ray, C. G., and Wedgwood, R. J. (1964). Neonatal listeriosis. Six case reports and a review of the literature. Pediatrics, 34, 378.

Rebuck, J. W., and Crowley, J. H. (1955). A method of studying leukocytic functions in vivo. Annals of the New York Academy of Sciences, 59, 757.

Remington, J. S., and Schafer, I. A. (1968). Transport piece in the urines of premature infants. Nature (London), 217, 364.

Rhodes, K., Markham, R. L., Maxwell, P. M., and Monk-Jones, M. E. (1969). Immunoglobulins and the X-chromosome. British Medical fournal, 3, 439.

Rich, A. R. (1951). The Pathogenesis of Tuberculosis, 2nd ed. C. C. Thomas, Springfield, Illinois.

Ridley, M., Barrie, D., Lynn, R., and Stead, K. C. (1970). Antibiotic resistant Staphylococcus aureus and hospital antibiotic policies. Lancet, 1, 230.

Robinow, M., and Simonelli, F. A. (1965). Fusobacterium bacteremia in the newborn. American fournal of Diseases of Children, 110, 92.
Robinson, S. C., Krause, V. W., Johnson, J., and Zwicker, B. (1965). Significance of maternal bacterial infection with respect to infection and disease in the newborn. Obstetrics and Gynecology, 25,664 .

Rogers, K. B. (1951). The spread of infantile gastro-enteritis in a cubicled ward. Fournal of Hygiene, 49, 140.

(1963). Epidemiology of hospital coliform enteritis. In Infection in Hospitals: Epidemiology and Control, p. 131. Ed. by R. E. O. Williams and R. A. Shooter. Blackwell, Oxford.

Rowe, B., Giles, C., and Brown, G. L. (1969). Outbreak of gastroenteritis due to Salmonella virchow in a maternity hospital. British Medical fournal, 3, 561.

Rozansky, R., and Bercovici, B. (1956). C-reactive protein during pregnancy and in cord blood. Proceedings of the Society for Experimental Biology and Medicine, 92, 4.

Rubbo, S. D., Gardner, J. F., and Franklin, J. C. (1966). Source of Psuedomonas aeruginosa infection in premature infants. Fournal of Hygiene, 64, 121.

Saccharow, L., and Pryles, C. V. (1969). Further experience with the use of percutaneous suprapubic aspiration of the urinary bladder: bacteriologic studies in 654 infants and children. Pediatrics, 43, 1018.

Salzman, T. C., Clark, J. J., and Klemm, L. (1967). Hand contamination of personnel as a mechanism of cross-infection in nosocomial infections with antibiotic-resistant Escherichia coli and Klebsiella-Aerobacter. Antimicrobial Agents and Chemotherapy, 7, 97.

- Scher, C. D., and Moss, R. (1967). Shigellae with transferable drug resistance: outbreak in a nursery for premature infants. fournal of Pediatrics, 71, 21.

Sarkany, I., and Gaylarde, C. C. (1967). Skin flora of the newborn. Lancet, 1, 589.

, and Gaylarde, C. C. (1968a). The effect of amniotic fluid on bacterial growth. British fournal of Dermatology, 80, 241.

, and Gaylarde, C. C. (1968b). Bacterial colonization of the skin of the newborn. Fournal of Pathology and Bacteriology, 95, 115.

Schaffer, A. J. (1960). Diseases of the Newborn. Saunders, Philadelphia and London.

Schlegel, R. J., and Bellanti, J. A. (1969). Increased susceptibility of males to infection. Lancet, 2, 826.

Seeliger, H. P. R. (1961). Listeriosis. Karger, Basle and New York.

Sever, J. L. (1959). Possible role of humidifying equipment in spread of infections from the newborn nursery. Pediatrics, 24, 50.

(1969). Immunoglobulin determinations for the detection of perinatal infections. Fournal of Pediatrics, 75, 1111.

Shallard, M. A., and Williams, A. L. (1965). A study of the carriage of gram-negative bacilli by new-born babies in hospital. Medical Fournal of Australia, 1, 540.

, and Williams, A. L. (1966). Studies on gram-negative bacilli in a ward for new-born babies. Medical fournal of Australia, 2, 455.

Sherman, J. D., Ingall, D., Wiener, J., and Pryles, C. V. (1960). Alcaligenes faecalis infection in the newborn. American fournal of Diseases of Children, 100, 212.

Shinefield, H. R., Ribble, J. C., Eichenwald, H. F., Boris, M., and Sutherland, J. M. (1963). Bacterial interference: its effect on nursery-acquired infection with Staphylococcus aureus. V. An analysis and interpretation. American fournal of Diseases of Children, 105, 683.

Shortland-Webb, W. R. (1968). Proteus and coliform meningoencephalitis in neonates. Fournal of Clinical Pathology, 21, 422.

Signy, A. G., and Bruce, R. D. (1932). Umbilical diphtheria. Archives of Disease in Childhood, 7, 43.

Silverman, W. A., Andersen, D. H., Blanc, W. A., and Crozier, D. N. (1956). A difference in mortality rate and incidence of kernicterus among premature infants allotted to two prophylactic antibacterial regimens. Pediatrics, 18, 614. ' -, and Sinclair, J. C. (1967). Evaluation of precautions before entering a neonatal unit. Pediatrics, 40, 900.

Simon, H. J., Yaffe, S. J., and Gluck, L. (1961). Effective control of staphylococci in a nursery. New England fournal of Medicine, 265, 1171.

Simpson, K., Tozer, R. C., and Gillespie, W. A. (1960). Prevention of staphylococcal sepsis in a maternity hospital by means of hexachlorophane. British Medical fournal, 1, 315.

Smallpeice, V. (1968). Urinary Tract Infection in Childhood and Its Relevance to Disease in Adult Life. Heinemann, London. 
Smith, J. A. (1969). Ophthalmia neonatorum in Glasgow. Scottish Medical fournal, 14, 272.

Smith, J. A. McC., Jennison, R. F., and Langley, F. A. (1956). Perinatal infection and perinatal death. Clinical aspects. Lancet, 2, 903.

Smith, J. W., and Bloomfield, A. L. (1950). The development of the aerobic bacterial flora of the throat in newborn babies. Fournal of Pediatrics, 36, 51 .

Smith, R. T. (1966). Human immunoglobulins: a guide to nomenclature and clinical application. Pediatrics, 37, 822.

, and Eitzman, D. V. (1964). The development of the immune response. Characterization of the response of the human infant and adult to immunization with salmonella vaccines. Pediatrics, 33, 163.

South, M. A., Cooper, M. D., Wollheim, F. A., and Good, R. A. (1968). The IgA system. II. The clinical significance of IgA deficiency: studies in patients with agammaglobulinemia and ataxia-telangiectasia. American fournal of Medicine, 44, 168.

$\longrightarrow,-,-$, Hong, R., and Good, R. A. (1966). The IgA system. I. Studies of the transport and immuno-chemistry of IgA in the saliva. Fournal of Experimental Medicine, 123, 615.

Spencer, G., Ridley, M., Eykyn, S., and Achong, J. (1968). Disinfection of lung ventilators by alcohol aerosol. Lancet, $2,667$.

Sprunt, K., and Redman, W. M. (1964). Vernix caseosa and bacteria. American fournal of Diseases of Children, 107, 125.

Stansfeld, J. M. (1962). The measurement and meaning of pyuria. Archives of Disease in Childhood, 37, 257.

Stenderup, A., Bach, A., Pedersen, G. T., and Rosendal, K. (1959). A staphylococcal epidemic in a maternity hospital. Acta Pathologica et Microbiologica Scandinavica, 45, 95.

Stetler, H., Martin, E., Plotkin, S., and Katz, M. (1970). Neonatal mastitis due to Escherichia coli. Fournal of Pediatrics, 76, 611 .

Stevenson, J. K., Graham, C. B., Oliver, T. K., Jr., and Goldenberg, V. E. (1969). Neonatal necrotizing enterocolitis. A report of twenty-one cases with fourteen survivors. American fournal of Surgery, 118, 260

Stiehm, E. R., and Damrosch, D. S. (1966). Neonatal meningococcal meningitis: report of a case acquired in the nursery. fournal of Pediatrics, 68, 654.

Stuart, K. L., Cummins, G. T. M., and Chin, W. A. (1965). Bacteriuria, prematurity, and the hypertensive disorders of pregancy. British Medical fournal, 1, 554.

Stuart, R. D. (1959). Transport medium for specimens in public health bacteriology. Public Health Reports, Washington, 74, 431.

Stulberg, C. S., Zuelzer, W. W., Nolke, A. C., and Thompson, A. L. (1955). Escherichia coli 0 127: $B_{8}$, a pathogenic strain causing infantile diarrhea. I. Epidemiology and bacteriology of a prolonged outbreak in a premature nursery. American fournal of Diseases of Children, 90, 125.

Thom, A. R., Cole, A. P., and Watrasiewicz, K. (i970). Pseudomonas aeruginosa infection in a neonatal nursery, possibly transmitted by a breast-milk pump. Lancet, 1, 560 .

Thompson, E. N., Chandra, R. K., Cope, W. A., and Soothill, J. F. (1969). Leucocyte abnormality in both parents of a patient with chronic granulomatous disease. Lancet, 1, 799.

Tillett, W. S., and Francis, T., Jr. (1930). Serological reactions in pneumonia with a non-protein somatic fraction of Pneumococcus. Fournal of Experimental Medicine, 52, 561 .

Tomasi, T. B., Jr., Tan, E. M., Solomon, A., and Prendergast, R. A. (1965). Characteristics of an immune system common to certain external secretions. Fournal of Experimental Medicine, $121,101$.

Torrey, J. C., and Reese, M. K. (1945). Initial aerobic flora of newborn infants. Selective tolerance of the upper respiratory tract for bacteria. American fournal of Diseases of Children, 69, 208.

Touloukian, R. J., Berdon, W. E., Amoury, R. A., and Santulli, T. V. (1967). Surgical experience with necrotizing enterocolitis in the infant. Fournal of Pediatric Surgery, 2, 389.

Trollope, A. (1861). Framley Parsonage. Smith and Elder, London.

Turck, M., Goffe, B. S., and Petersdorf, R. G. (1962). Bacteriuria of pregnancy. Relation to socioeconomic factors. New England Journal of Medicine, 266, 857.

Urmenyi, A. M. C., and Franklin, A. W. (1961). Neonatal death from pigmented coliform infection. Lancet, 1, 313.

Vahlquist, B. (1960). Neonatal immunity. American fournal of Diseases of Children, 99, 729.
Valdes-Dapena, M., and Miller, W. H. (1955). Pericarditis in the newborn. Pediatrics, 16, 673.

Valman, H. B., and Wilmers, M. J. (1969). Use of antibiotics in acute gastroenteritis among infants in hospital. Lancet, 1,1122 .

Victorin, L. (1967). An epidemic of otitis in newborns due to infection with Pseudomonas aeruginosa. Acta Paediatrica Scandinavica, 56, 344.

Virtanen, S., Oksanen, T., and Peltonen, T. (1962). Colony counts and the diagnosis of urinary tract infection in infants and children. Counts from clean-voided urine specimens and from those collected in plastic bags. Annales Paediatriae Fenniae, 8, 269.

Wallach, E. E., Brody, J. I., and Oski, F. A. (1969). Fetal immunization as a consequence of bacilluria during pregnancy. Obstetrics and Gynecology, 33, 100.

Walsh, H., Hildebrandt, R. J., and Prystowsky, H. (1965). Growth inhibition factors in amniotic fluid. American fournal of Obstetrics and Gynecology, 93, 590.

Washburn, T. C., Medearis, D. N., Jr., and Childs, B. (1965). Sex differences in susceptibility to infections. Pediatrics, 35, 57.

Watson, D. G. (1957). Purulent neonatal meningitis. A study of forty-five cases. Fournal of Pediatrics, 50, 352.

Watt, P. J., and Okubadejo, O. A. (1967). Changes in incidence and aetiology of bacteraemia arising in hospital practice. British Medical fournal, 1, 210.

Weathers, W. T., and Wenzl, J. E. (1969). Suprapubic aspiration of the bladder. Perforation of a viscus other than the bladder. American fournal of Diseases of Children, 117, 590.

Weinstein, L. (1938). The bacterial flora of the human vagina. Yale fournal of Biology and Medicine, 10, 247.

- Goldfield, M., and Adamis, D. (1953). A study of intrathecal therapy in bacterial meningitis. Medical Clinics of North America, 37, 1363.

Williams, C. P. S., and Oliver, T. K., Jr. (1969). Nursery routines and staphylococcal colonization of the newborn. Pediatrics, 44, 640.

Williams, D. I., and Martins, A. G. (1960). Periprostatic haematoma and prostatic abscess in the neonatal period. Archives of Disease in Childhood, 35, 177.

Williams, R. E. O. (1961). Carriage of staphylococci in the newborn. A comparison of infants born at home with those born in hospital. Lancet, 2, 173.

Willis, M. D., and Austin, W. J. (1966). Human Vibrio fetus infection. Report of two dissimilar cases. American fournal of Diseases of Children, 112, 459.

Wilson, M. G., and Armstrong, D. H. (1964). Inflammation of the umbilical cord and neonatal illness. American fournal of Obstetrics and Gynecology, 90, 843.

- , Nelson, R. C., Phillips, L. H., and Boak, R. A. (1961). New source of Pseudomonas aeruginosa in a nursery. Fournal of the American Medical Association, 175, 1146.

Winters, J. L., and Cahen, I. (1960). Acute hematogenous osteomyelitis. A review of sixty-six cases. fournal of Bone and foint Surgery, 42A, 691.

Winton, F. W., and Keay, A. J. (1968). Bacteria in a hospital nursery: Laboratory and clinical studies. Fournal of Hygiene, 66, 325.

Wolinsky, E., Lipsitz, P. J., Mortimer, E. A., Jr., and Rammelkamp, C. H., Jr. (1960). Acquisition of staphylococci by newborns. Direct versus indirect transmission. Lancet, 2,620 .

Wren, B. G. (1969). Subclinical renal infection and prematurity. Medical fournal of Australia, 2, 596.

Wright, A. E., and Douglas, S. R. (1903). An experimental investigation of the role of the blood fluids in connection with phagocytosis. Proceedings of the Royal Society, 72, 357.

Xanthou, M. (1970). Leucocyte blood picture in healthy full-term and premature babies during neonatal period. Archives of Disease in Childhood, 45, 242.

Yu, J. S., and Grauaug, A. (1963). Purulent meningitis in the neonatal period. Archives of Disease in Childhood, 38, 391.

\section{Addendum}

The higher incidence of maternal chorioamnionitis and congenital pneumonia in the Negro has recently been confirmed by Naeye and Blanc (1970), in a study of over a 1,000 stillbirths and neonatal deaths. They report 
a close correlation with poverty, congenital pneumonia occurring twice as often in the poorest families compared with the most prosperous. (A lower standard of personal hygiene may be an important factor in pregnancy bacteriuria (see above) and maternal chorioamnionitis alike.) The poorest Negroes, however, fared even worse than Puerto Rican and white families in identical income groups, despite apparently similar hospital care, giving further support to a possible genetic basis for the differences. Naeye and Blanc doubt whether antenatal hypoxia is a feature of congenital pneumonia: mean Apgar scores at birth did not differ from those of infants dying without this condition, and they found no aspiration of particulate matter (chiefly vernix) into the lung. As the mean Apgar score of all their neonatal deaths was low, not surprisingly, and as vernix is not found until relatively late in intrauterine life-the mean gestational age of their cases of pneumonia and of a small number of other bacterial infection being 29 weeks-this conclusion may be questioned.

This work and a combined morphological, bacterio- logical, and clinical study not confined to stillbirths or neonatal deaths by Olding (1970), who has been unable to prove that bacterial infection is the main cause of chorioamnionitis, reveal the wide divergence of opinion on this subject, which may be the result of the study of different populations, and of necropsy material as opposed to that from all births. It seems to the writer that the incidence of congenital 'pneumonia' should still lessen considerably as stillbirth rates fall with better obstetric care, and as resuscitation of the infant improves. This presupposes of course that such care, in addition to being generally available, is actively sought.

\section{REFERENCES}

Naeye, R. L., and Blanc, W. A. (1970). Relation of poverty and race to antenatal infection. Nerw England fournal of Medicine, 283, 555.

Olding, L. (1970). Value of placentitis as a sign of intrauterine infection in human subjects. A morphological, bacteriological, clinical and statistical study. Acta Pathologica et Microbiologica Scandinavica, section A, 78, 256. 